\title{
Therapeutic importance of synthetic thiophene
}

\author{
Rashmi Shah and Prabhakar Kumar Verma*
}

\begin{abstract}
Thiophene and its substituted derivatives are very important class of heterocyclic compounds which shows interesting applications in the field of medicinal chemistry. It has made an indispensable anchor for medicinal chemists to produce combinatorial library and carry out exhaustive efforts in the search of lead molecules. It has been reported to possess a wide range of therapeutic properties with diverse applications in medicinal chemistry and material science, attracting great interest in industry as well as academia. It has been proven to be effectual drugs in present respective disease scenario. They are remarkably effective compounds both with respect to their biological and physiological functions such as anti-inflammatory, anti-psychotic, anti-arrhythmic, anti-anxiety, anti-fungal, antioxidant, estrogen receptor modulating, anti-mitotic, anti-microbial, kinases inhibiting and anti-cancer. Thus the synthesis and characterization of novel thiophene moieties with wider therapeutic activity is a topic of interest for the medicinal chemist to synthesize and investigate new structural prototypes with more effective pharmacological activity. However, several commercially available drugs such as Tipepidine, Tiquizium Bromides, Timepidium Bromide, Dorzolamide, Tioconazole, Citizolam, Sertaconazole Nitrate and Benocyclidine also contain thiophene nucleus. Therefore, it seems to be a requirement to collect recent information in order to understand the current status of the thiophene nucleus in medicinal chemistry research.
\end{abstract}

Keywords: Thiophene, Heterocyclic compounds, Combinatorial library, Antimicrobial

\section{Introduction}

As the world's population is increasing at an alarming rate, health problems have also become a very serious clinical problem. Therefore, it is an urgent requirement for the scientist to design and discover new drug molecules which possibly offers some of the greatest hopes for success in present and future epoch. However, there are still enormous numbers of pharmacologically active heterocyclic compounds which are in regular clinical use [1]. Heterocyclic compounds are extensively distributed in nature and have versatile synthetic applicability and biological activity which helped the medicinal chemist to plan, organize and implement new approaches towards the discovery of novel drugs [2].

Thiophene (Fig. 1) is a five membered heteroaromatic compound containing a sulfur atom at 1 position. It is

*Correspondence: vermapk422@rediffmail.com

Department of Pharmaceutical Sciences, Maharshi Dayanand University, Rohtak, Haryana 124001, India considered to be a structural alert with formula $\mathrm{C}_{4} \mathrm{H}_{4} \mathrm{~S}$, chemical name is thiacyclopentadiene [3].

Thiophene was discovered as a contaminant in benzene [4]. It has the molecular mass of $84.14 \mathrm{~g} / \mathrm{mol}$, density is $1.051 \mathrm{~g} / \mathrm{ml}$ and Melting Point is $-38^{\circ} \mathrm{C}$. It is soluble in most organic solvents like alcohol and ether but insoluble in water. The "electron pairs" on sulfur are significantly delocalized in the $\pi$ electron system and behaves extremely reactive like benzene derivative. Thiophene forms a azeotrope with ethanol like benzene. The similarity between the physicochemical properties of benzene and thiophene is remarkable. For example, the boiling point of benzene is $81.1^{\circ} \mathrm{C}$ and that of thiophene is $84.4{ }^{\circ} \mathrm{C}$ (at $760 \mathrm{mmHg}$ ) and therefore, both are a well known example of bioisosterism [5]. It can be easily sulfonated, nitrated, halogenated, acylated but cannot be alkylated and oxidized [3].

In medicinal chemistry, thiophene derivatives are very important heterocycles exhibiting remarkable applications in different disciplines. In medicine, 


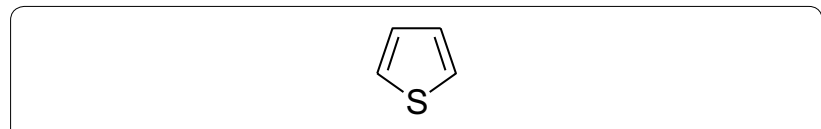

Fig. 1 Thiophene

thiophene derivatives shows antimicrobial [6], analgesic and anti-inflammatory [7], antihypertensive [8], and antitumor activity [9] while they are also used as inhibitors of corrosion of metals [10] or in the<smiles>Cc1cc(C(C)N(O)C(N)=O)c(C)s1</smiles>

1-(1-(2,5-Dimethylthiophen-3-yl) ethyl)-1-hydroxyurea fabrication of light-emitting diodes in material science [11].

\section{Biological activities of thiophene derivatives}

Thiophene nucleus containing compounds show various activities like for example 1-[1-(2,5-dimethylthiophen3-yl)ethyl]-1-hydroxyurea (1) act as an anti-inflammatory agent; the maleate salt of 1-(2,5-dimethylthiophen-3-yl)3-(5-methyl-1H-imidazol-4-yl)propan-1-one (2) work as serotonin antagonists and is used in the treatment of Alzheimer's disease.
1-(2,5-Dimethylthiophen-3-yl)-3-

(5-methyl-1H-imidazol-4-yl)propan-1-one

2

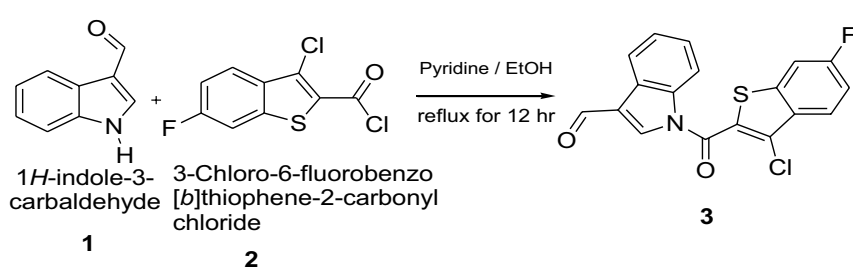

4-(1-(3-Chloro-6-fluoro-1-benzo[b]thiophene

7, 8-tetrahydr-indol-3-yl)7, 7-dimethyl-3, 4,

4

Scheme 1 Synthesis of 4-(1-(3-chloro-6-fluoro-1-benzo[b]thiophene-2-carbonyl)-1H-indol-3-yl)-7,7-dimethyl-3,4,7,8-tetrahydroquinazoline 2,5(1H,6H)dione

Table 1 Biological activity of synthesized compounds

\begin{tabular}{|c|c|c|c|c|c|c|}
\hline \multirow[t]{3}{*}{ S. no. } & \multicolumn{4}{|c|}{ Antibacterial strains } & \multirow{2}{*}{\multicolumn{2}{|c|}{ Antifungal strains }} \\
\hline & \multicolumn{2}{|c|}{ Gram negative } & \multicolumn{2}{|c|}{ Gram positive } & & \\
\hline & E. coli & P. aeruginosa & S. Aureus & C. albicans & A. niger & A. clavatus \\
\hline 4 & 500 & 100 & 250 & 250 & 100 & 100 \\
\hline SD & 100 & 100 & 50 & 100 & 100 & 100 \\
\hline
\end{tabular}

Minimum inhibitory concentrations was expressed as $(\mu \mathrm{g} / \mathrm{ml})$

$\mathrm{SD}=$ Ampicillin for antibacterial drug; $\mathrm{SD}=$ Griseofulvin for antifungal drug 


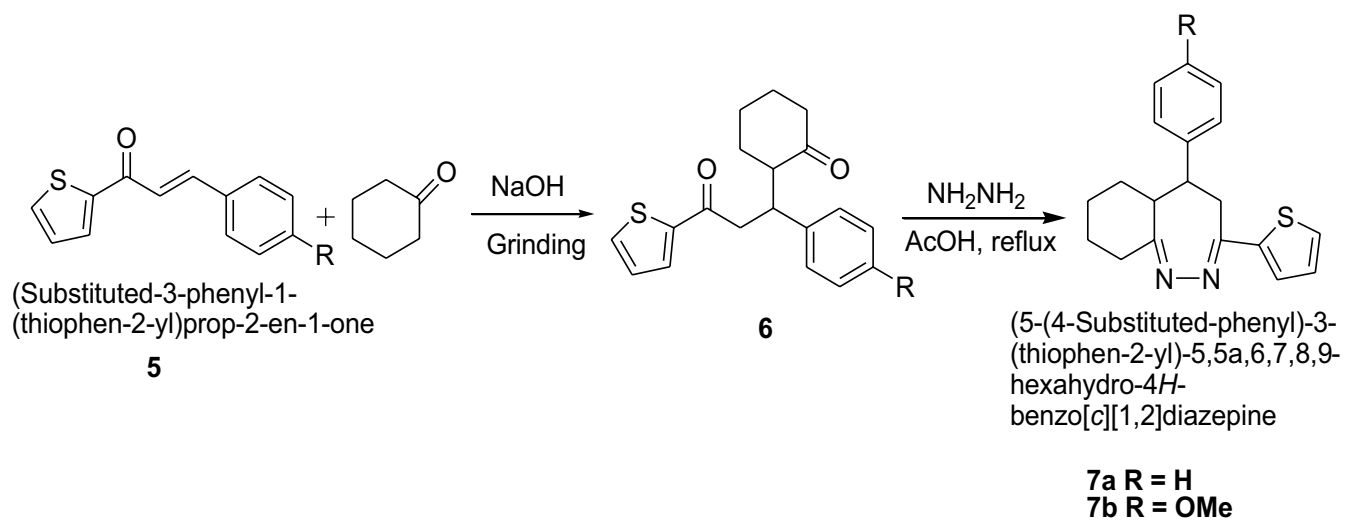

Scheme 2 Synthesis of diazepines (7a, 7b)

Table 2 Antimicrobial activity of thiophen-2-yl-chalcone derived heterocyclic compounds

\begin{tabular}{llllll}
\hline S. no. & S. aureus & E. coli & B. subtilis & $\begin{array}{l}\boldsymbol{P} \text {. } \\
\text { aeruginosa }\end{array}$ & C. albicans \\
\hline 7a & 0.313 & 0.625 & 0.625 & 0.313 & 0.313 \\
7b & 0.313 & 0.625 & 0.625 & 0.313 & 0.313 \\
$\begin{array}{l}\text { Ciprofloxa- } \\
\quad \text { cin }\end{array}$ & 0.625 & 0.625 & 0.625 & 0.625 & - \\
Fluconazole & - & - & - & - & 0.625 \\
\hline
\end{tabular}

Minimum inhibitory concentration (MIC; $\mu \mathrm{g} / \mathrm{ml}$ )

2-Butylthiophene (3) is used as a raw material in the synthesis of anticancer agents and 2-octylthiophene (4) is used in the synthesis of anti-atherosclerotic agents such as (5). It also act as metal complexing agents and in the development of insecticides.

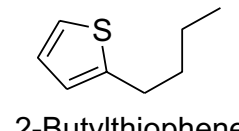

2-Butylthiophene

3

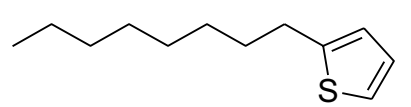

2-Octylthiophene

4
The higher alkylated thiophenes (6) has been used extensively as a raw material in patents relating to liquid crystals [12].

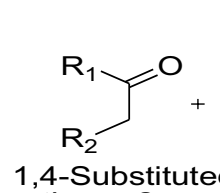

1,4-Substituted -ethane-2-one

8<smiles>CCOC(=O)CC#N</smiles>

9

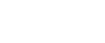

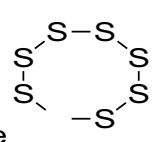

Sulphur

10

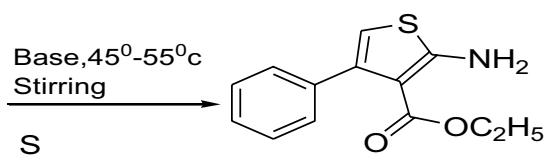

11

Ethyl 2-(4-hydroxyphenylamino)-4phenylthiophene-3-carboxylate

12

Scheme 3 Synthesis of ethyl 2-(4-hydroxyphenylamino)-4-phenylthiophene-3-carboxylate 
<smiles>CCCc1ccc(CNc2cccc(CCC(=O)OC)c2)s1</smiles>

Ethyl 3-(3-((5-octylthiophen-2-yl)methyl amino)phenyl)propanoate

5

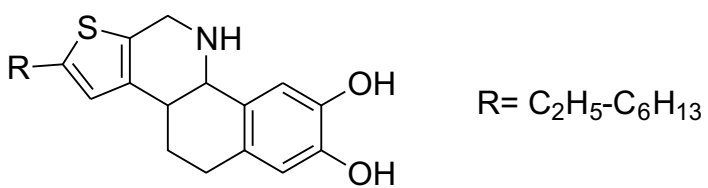

Alkylated derivatives of thiophene

6
Table 3 Antimicrobial activity of 2-aminothiophene derivatives

\begin{tabular}{lllll}
\hline S. no. & P. vulgaris & B. subtilis & E. coli & S. aureus \\
\hline $\mathbf{1 2}$ & 25 & 50 & 12.5 & 50 \\
Ampicillin & 25 & 50 & 12.5 & 50 \\
Streptomycin & 12.5 & 50 & 12.5 & 25 \\
\hline
\end{tabular}

Minimum inhibitory concentration $(\mu \mathrm{g} / \mathrm{ml})$

\section{Antimicrobial activity}

Thiophene derivatives show high antimicrobial activity against various microbial infections. Different approaches were made to prove thiophene as antimicrobial agent by different scientist for the discovery of most active thiophene derivatives to the present scenario [13].

Mehta et al. [14] developed a new class of 4-(1-(3-chlorobenzo[ $b]$ thiophene-2-carbonyl)- $1 H$-indol-3-yl)-7, 7-dimethyl-3,4,7,8-tetrahydroquinazoline

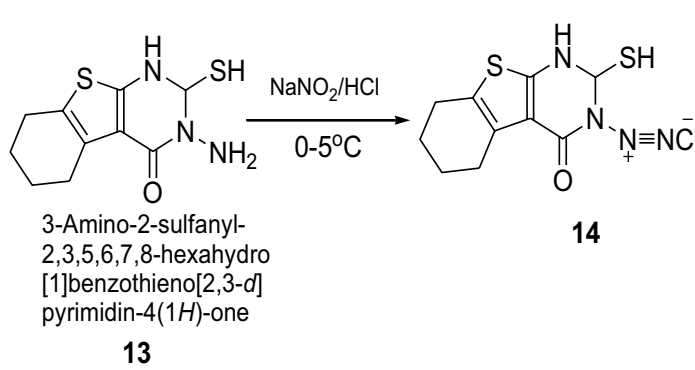<smiles>C(=NNc1ccccc1)c1ccccc1</smiles><smiles>[R][R]1cccc(/C(N=NN2C(=O)c3c(sc4c3CCCC4)NC2S)=N/N)c1</smiles>

$3-\{[($ Phenyl hydrazono)(substituted phenyl) methyl] diazenyl\}-2-sulfanyl-2,3,5,6,7,8-hexa hydro[1]benzothieno[2,3- $d$ ]pyrimidin-4(1H)-one

$15 a-i$

\begin{tabular}{cc}
\hline Compound code & $\mathbf{R}$ \\
\hline $\mathbf{1 5}$ & $\mathrm{H}$ \\
$\mathbf{1 5} \mathbf{b}$ & $2-\mathrm{Cl}$ \\
$\mathbf{1 5 d}$ & $4-\mathrm{NO}_{2}$ \\
$\mathbf{1 5} \mathbf{c}$ & $3,4,5-\mathrm{OCH}_{3}$ \\
$15 \mathbf{f}$ & $2-\mathrm{NO}_{2}$ \\
$15 \mathbf{g}$ & $\left.4-\mathrm{N}_{2} \mathrm{CH}_{3}\right)_{2}$ \\
$15 \mathbf{h}$ & $3,4-\mathrm{OCH}_{3}$ \\
$\mathbf{1 5 i}$ & $4-\mathrm{OCH}_{3}$
\end{tabular}

Scheme 4 Synthesis of 3-\{[(phenylhydrazono)(substitutedphenyl)methyl]diazenyl\}-2-sulfanyl-2,3,5,6,7,8-hexahydro [1] benzothieno[2,3-d] pyrimidin-4(1H)-one (15a-i) 
Table 4 Antimicrobial activity of benzothieno[2,3-c] chromen-6-one derivatives

\begin{tabular}{lllll}
\hline Compound & \multicolumn{2}{l}{ Antibacterial } & Antifungal \\
\cline { 2 - 4 } & B. subtilis & E. coli & P. aureginosa & C.albicans \\
\hline $\mathbf{1 5 a}$ & 11 & 00 & 15 & 10 \\
$\mathbf{1 5 b}$ & 00 & 10 & 00 & 14 \\
$\mathbf{1 5 c}$ & 12 & 00 & 12 & 12 \\
$\mathbf{1 5 d}$ & 00 & 14 & 13 & 00 \\
$\mathbf{1 5 e}$ & 00 & 10 & 11 & 00 \\
$\mathbf{1 5 f}$ & 00 & 00 & 00 & 12 \\
$\mathbf{1 5} \mathbf{g}$ & 14 & 00 & 14 & 11 \\
$\mathbf{1 5} \mathbf{h}$ & 12 & 10 & 12 & 13 \\
$\mathbf{1 5 i}$ & 14 & 11 & 12 & 12 \\
Ampicillin & 15 & 18 & 20 & - \\
Fluconazole & - & - & - & 15
\end{tabular}

Minimum inhibitory concentrations was expressed as $(\mu \mathrm{g} / \mathrm{ml})$
2,5(1H,6H)dione thiophene derivatives (Scheme 1). These synthesized compounds were screened for their antibacterial activity against three bacterial strains viz. E. coli, $P$. aeruginosa, S. aureus and three fungal strains viz. $C$. albicans, A. niger, A. Clavatus using serial broth dilution method. The standard drug used in this study was 'Ampicillin' for evaluating antibacterial activity which showed (50, 100, and $50 \mu \mathrm{g} / \mathrm{ml}) \mathrm{MIC}$ against E. coli, P. aeruginosa and $S$. aureus, respectively. For antifungal activity 'Griseofulvin' was used as a standard drug, which showed $(100,100$, and $100 \mu \mathrm{g} / \mathrm{ml}) \mathrm{MIC}$ against C. albicans, $A$. niger, and $A$. clavatus, respectively. Among the synthesized derivatives, Compound $\mathbf{4}$ was found to be good active against $P$. aeruginosa. For the antifungal activity compounds 4 was considered as good active against $A$. niger and $A$. clavatus. The results of synthesized compounds presented in Table 1.<smiles>COc1cc(/C=C\C(=O)O)cc([N+](=O)[O-])c1</smiles>

16<smiles>[R]c1c([R])c([R])c2c(oc(=O)c3sc4c([N+](=O)[O-])cc(OC)cc4c32)c1[N+](=O)[O-]</smiles>

10-Methoxy-4,8-dinitro-6H-benzothieno<smiles>[R]c1c(C)cc(O)c([N+](=O)[O-])c1C</smiles>
$[2,3-c]$ chromen-6-one derivatives

19

20a-c

\begin{tabular}{llll}
\hline Compound & $\mathrm{R}$ & $\mathrm{R} 1$ & $\mathrm{R} 2$ \\
\hline $\mathbf{2 0 a}$ & $-\mathrm{H}$ & $-\mathrm{NO}_{2}$ & $-\mathrm{H}$ \\
$\mathbf{2 0 b}$ & $-\mathrm{H}$ & $-\mathrm{CH}_{3}$ & $-\mathrm{H}$ \\
$\mathbf{2 0 c}$ & $-\mathrm{OCH}_{3}$ & $-\mathrm{H}$ & $-\mathrm{H}$ \\
\hline
\end{tabular}

Scheme $\mathbf{5}$ Synthesis of 10-methoxy-4,8-dinitro-6H-benzothieno[2,3-c]chromen-6-one derivatives (20a-c)

Table 5 Antimicrobial activity of benzothienopyrimidinone derivatives

\begin{tabular}{|c|c|c|c|c|c|c|c|c|}
\hline \multirow[t]{2}{*}{ Compd } & \multicolumn{2}{|l|}{ S. aureus } & \multicolumn{2}{|l|}{ E. coli } & \multicolumn{2}{|c|}{ B. Subtilis } & \multicolumn{2}{|c|}{ S. typhosa } \\
\hline & $2 \mu \mathrm{g} / \mathrm{ml}$ & $5 \mu \mathrm{g} / \mathrm{ml}$ & $2 \mu \mathrm{g} / \mathrm{ml}$ & $5 \mu \mathrm{g} / \mathrm{ml}$ & $2 \mu \mathrm{g} / \mathrm{ml}$ & $5 \mu \mathrm{g} / \mathrm{ml}$ & $2 \mu \mathrm{g} / \mathrm{ml}$ & $5 \mu \mathrm{g} / \mathrm{ml}$ \\
\hline $20 a$ & - & + & + & ++ & - & + & + & ++ \\
\hline $20 \mathrm{~b}$ & + & + & + & + & + & ++ & + & + \\
\hline $20 c$ & - & + & + & + & - & + & + & + \\
\hline
\end{tabular}




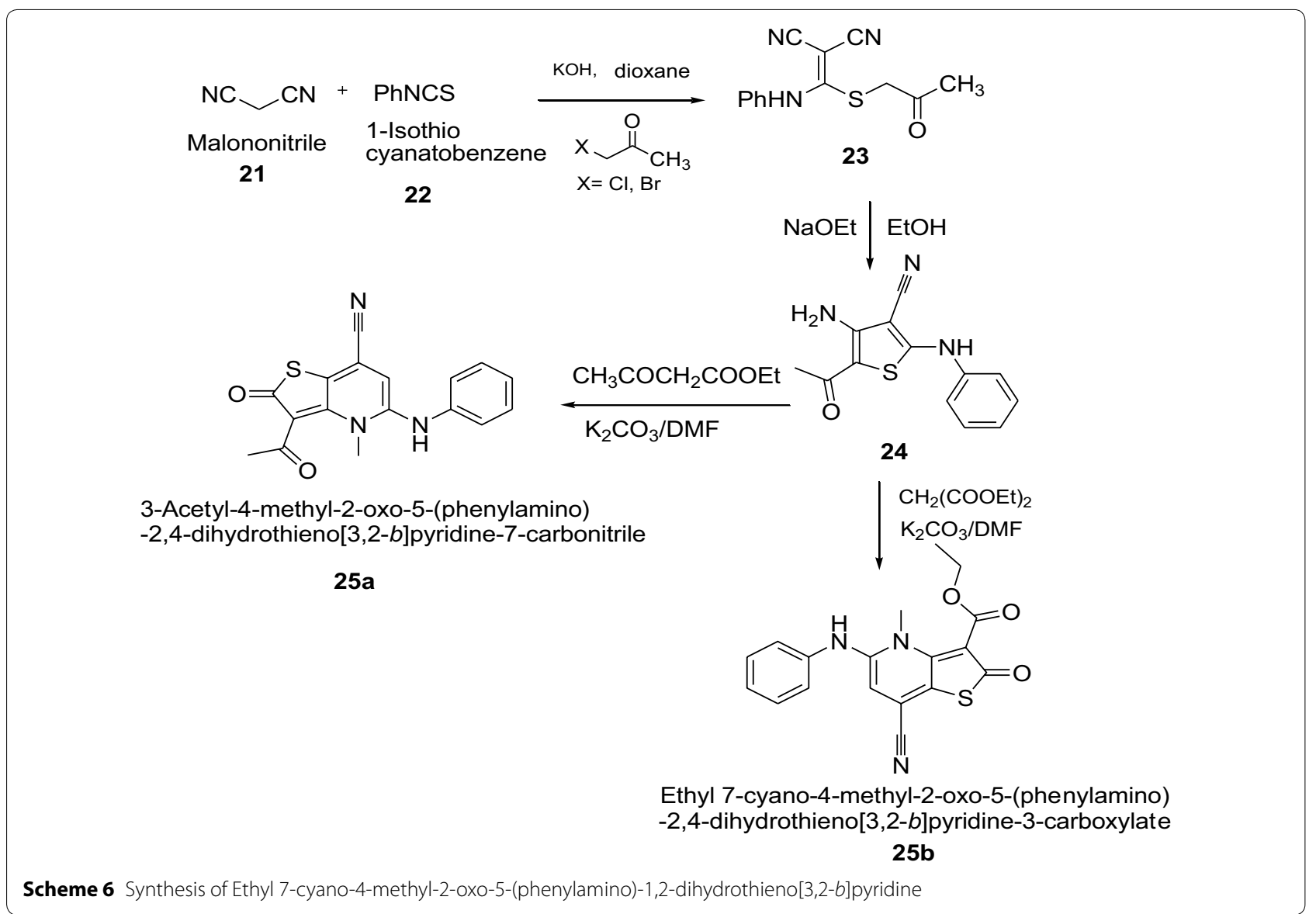

Table 6 The in vitro antibacterial of the synthesized thienopyridines derivatives

\begin{tabular}{llllll}
\hline Compound & \multicolumn{2}{l}{ Gram-positive species } & & \multicolumn{2}{l}{$\begin{array}{l}\text { Gram-negative } \\
\text { species }\end{array}$} \\
\cline { 2 - 3 } \cline { 5 - 6 } & B. Subtilis & S. aureus & & E. coli & S. typhosa \\
\hline $\mathbf{2 5 a}$ & 12.5 & 12.5 & & 25 & 50 \\
$\mathbf{2 5 b}$ & 6.3 & 12.5 & & 25 & 50 \\
\hline
\end{tabular}

Minimum Inhibitory Concentrations was expressed as $(\mu \mathrm{g} / \mathrm{ml})$

Mazimba [15] synthesized thiophene analogues of chalcones in good yields by condensation of 2-acetylthiophene and salicylaldehydes using Scheme 2. 1,5-Diketones were formed by solvent-free michael addition of cyclohexanone and 2-thienylchalcones devoid of hydroxyl groups which were used as synthons for synthesis of diazepines. The synthesized compounds were screened for in vitro antimicrobial activities against S. aureus, E. coli, B. subtilis, P. Aeruginosa and C. Albicans using dilution method. The compounds were found to show moderate to good antibacterial and antifungal activities. Among the tested compounds, diazepines (7a, b) exhibited excellent antibacterial (S. aureus and $P$. aeruginosa) and antifungal (C. albicans) activities. The results showed the importance of the carbon-nitrogen bond in biological systems because of which antimicrobial activities for these $\mathrm{N}$-containing compounds were reported. The results of synthesized compounds showed in Table 2.

Prasad et al. [16] synthesized newly ethyl 2-amino4-phenylthiophene-3-carboxylate derivatives using Scheme 3. The synthesized compounds were screened for their antibacterial activity by using minimum inhibitory concentration (MIC) method by taking ampicillin and streptomycin as standard drug. Among all the synthesized derivatives, compound $\mathbf{1 2}$ showed greater inhibitory effect against the organisms used, particularly against $B$. subtilis, E. coli, P. vulgaris and $S$. aureus with MIC. The present study has given deep insight as the 2-aminothiophene bearing 4-hydroxy benzaldehyde shown significant anti-microbial activity. The compound 12 showed the significant anti-microbial activity among all the synthesized 2-aminothiophene derivatives because of the presence of 4-hydroxy benzaldehyde at second 


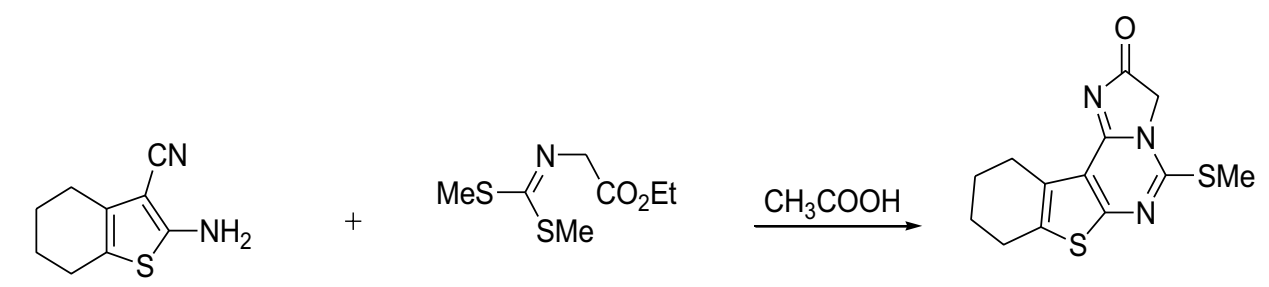

2-Amino-4,5,6,7-tetrahydro Ethyl 2-(bis(methylthio) benzo $[b]$ thiophene-3-carbonitrile methyleneamino)acetate

26

27<smiles>NC(=O)C1CCCc2c1sc1nc[nH]c(=O)c21</smiles>

30<smiles>CCOC(=O)c1c(N)sc2c1CCCC2</smiles>

Ethyl 2-amino-4,5,6,7-tetrahydro benzo[ $b]$ thiophene-3-carboxylate

29
5-Methylthio-8,9,10,11-tetrahydro benzothieno[3,2-e]-imidazo[1,2-c] pyrimidin-2(3H)-one<smiles>CCOC(=O)COC(C)=O</smiles>

4-(3,5-Dimethylpyrazolyl)-5,6,7,8-tetra hydrobenzothieno[2,3-d]pyrimidine
28<smiles>ClC1NC=Nc2sc3c(c21)CCCC3</smiles>

31

33<smiles>NC1NC=Nc2sc3c(c21)CCCC3</smiles>

32

Scheme 7 Synthesis of thienopyrimidine derivatives

Table 7 Antibacterial activity of some synthesized compounds

\begin{tabular}{llll}
\hline Compound & \multicolumn{4}{l}{ Zone of inhibition $(\mathbf{m m})$} \\
\cline { 2 - 4 } & B. cereus & S. dysenteriae & S. typhi \\
\hline $\mathbf{2 8}$ & 20 & 13 & 26 \\
$\mathbf{3 3}$ & 31 & 28 & 29 \\
Ampicillin & 21 & 30 & 24 \\
\hline
\end{tabular}

$1 \mathrm{mg} / \mathrm{ml}$ per disc

Table 8 Antifungal activity of some synthesized compounds

\begin{tabular}{lllll}
\hline Compound & \multicolumn{4}{l}{ Inhibition of mycelial growth (\%) } \\
\cline { 2 - 5 } & M. phaseolina & F. equiseti & A. alternate & C. corchori \\
\hline $\mathbf{2 8}$ & 34.5 & 37.5 & 54 & 50 \\
$\mathbf{3 3}$ & 48.3 & 65.6 & 65.4 & 54.5 \\
Nystatin & 71.8 & 44.7 & 51.6 & 40.5 \\
\hline
\end{tabular}

a $1 \mathrm{mg} / \mathrm{ml}$ per disc position. The results of synthesized compounds presented in Table 3.

Lakshmi et al. [17] synthesized $3-\{[($ phenylhydrazono) (substituted phenyl)methyl]diazenyl\}-2-sulfanyl-2,3,5,6,7,8-hexahydro [1] benzothieno[2,3- $d$ ] pyrimidin-4(1H)-one derivatives by using Scheme 4 . All the synthesized compounds were screened for their antibacterial and antifungal activities against various microbes such as B. subtilis, E. coli, P. aeruginosa and $C$. albicans by the cup-plate agar diffusion method. From all the series, compounds $15 \mathrm{a}, 15 \mathrm{c}, 15 \mathrm{~g}, 15 \mathrm{~h}, 15 \mathrm{i}$ were active against $B$. subtilis, compounds $15 \mathbf{b}, 15 \mathbf{d}, 15 \mathbf{e}, 15 \mathbf{h}$, $15 \mathbf{i}$ were active against $E$. coli, compounds $15 \mathbf{a}, 15 \mathrm{c}, 15 \mathrm{~d}$, $15 \mathrm{e}, 15 \mathrm{~g}, 15 \mathrm{~h}, 15 \mathrm{i}$ showed activity against $P$. aeruginosa and compounds 15a, 15b, 15c, 15f, 15g, 15h, 15i were found active against $C$. albicans. The results of synthesized compounds showed in Table 4.

Havaldar et al. [18] synthesized 10-methoxy-4,8-dinitro-6 $H$-benzothieno[2,3-c] chromen-6-one derivatives by using Scheme 5 . All the synthesized compounds were tested for their antibacterial activity against S. aureus, 


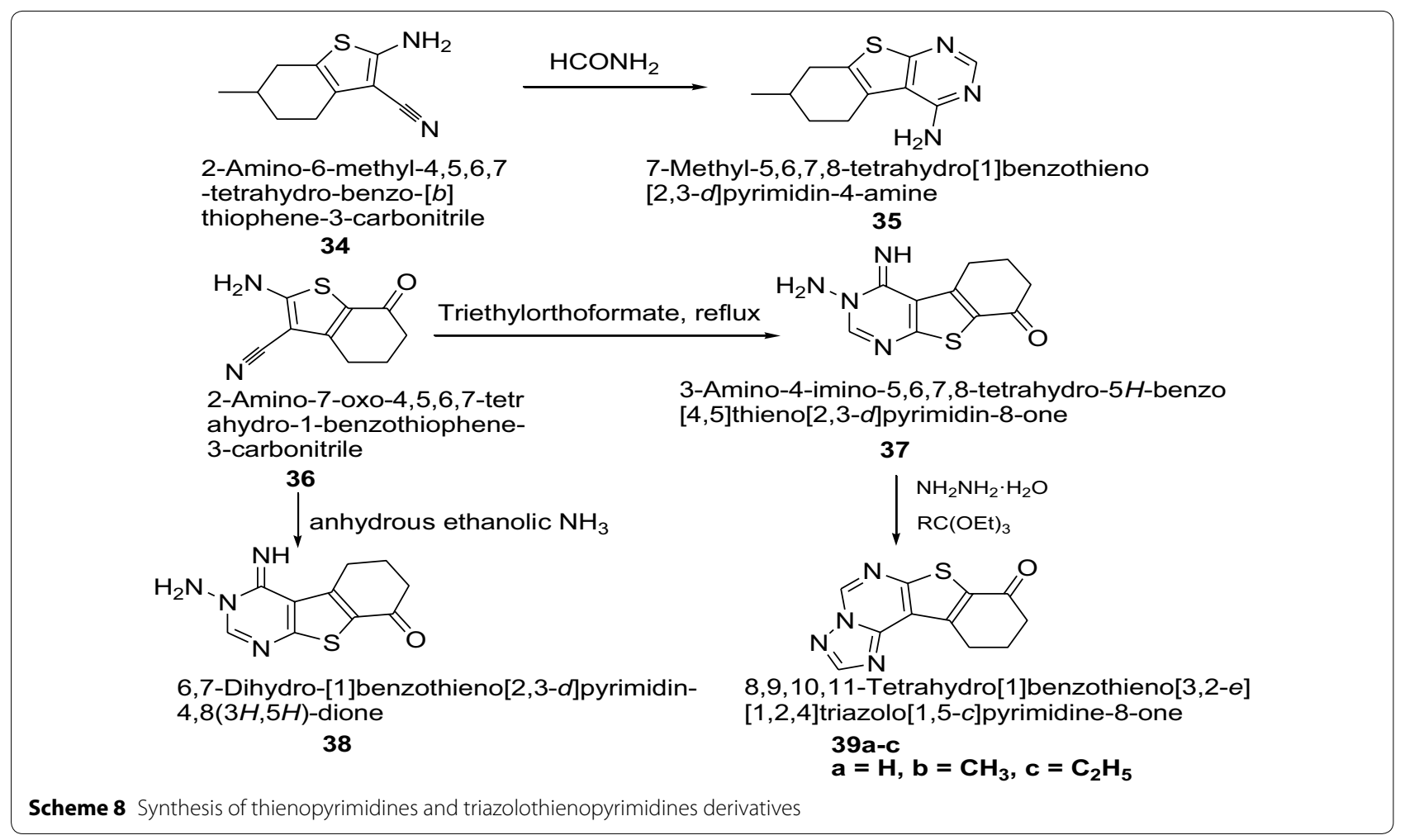

Table 9 Antibacterial and antifungal activities of the compounds as MIC values $(\mu \mathrm{g} / \mathrm{ml})$

\begin{tabular}{lllllll}
\hline Compounds & S. aureus & B. subtilis & E. coli & P. aeruginosa & C. albicans & C. parapsilosis \\
\hline $\mathbf{3 5}$ & 256 & 11 & 128 & 256 & 128 & 64 \\
$\mathbf{3 7}$ & 512 & 256 & 256 & 256 & 16 & 128 \\
$\mathbf{3 8}$ & 512 & 11 & 256 & 256 & 128 & 256 \\
$\mathbf{3 9 a}$ & 128 & 11 & 128 & 256 & 256 & 128 \\
$\mathbf{3 9 b}$ & 256 & 11 & 128 & 256 & 128 & 64 \\
$\mathbf{3 9 c}$ & 128 & 11 & 256 & 128 & - & 64 \\
Ampicillin & 4 & 8 & 4 & - & 8 & - \\
Fluconazole & - & - & - & - & & 0.25 \\
\hline
\end{tabular}

E. coli, B. subtilis and S. typhosa using concentrations of 2 and $5 \mu \mathrm{g} / \mathrm{ml}$ by the ditch plate technique. Among all the series, the compounds $20 \mathbf{b}$ showed a much higher inhibitory effect on the growth of bacteria because of the presence of $\mathrm{CH}_{3}$ group. The results of synthesized compounds presented in Table 5.

Ahmed et al. [19] synthesized thieno[3,2- $b$ ] pyridine2 -one derivatives by using Scheme 6 . The synthesized thienopyridines derivatives were evaluated for their in vitro antibacterial activity against two grampositive (B. subtilis and $S$. aureus) and two Gram-negative (E. coli and S. typhi) strains using paper disk diffusion assay method by comparing with amoxicillin $(30 \mu \mathrm{g} /$ disk) as reference antibiotic. The compounds 25a and 25b showed remarkable biological activity because of the substitution of the $\mathrm{CN}$ (at C3) either by acetyl (as in 25a) and/or ethoxycarbonyl (as in 25b). However, the antibacterial activity was slightly hampered by the existence of the electron withdrawing $p$-bromophenyl group at fourth position of carbon. The results of synthesized compounds presented in Table 6.

Bhuiyan et al. [20] synthesized a novel class of $[1,2,4]$ triazolo[4,3-c]thieno-[3,2-e] pyrimidine derivatives using Scheme 7 and assayed for the antibacterial activity against $B$. cereus, $S$. dysenteriae and S. typhi and for antifungal activity against $M$. phaseolina, F. equiseti, A. 


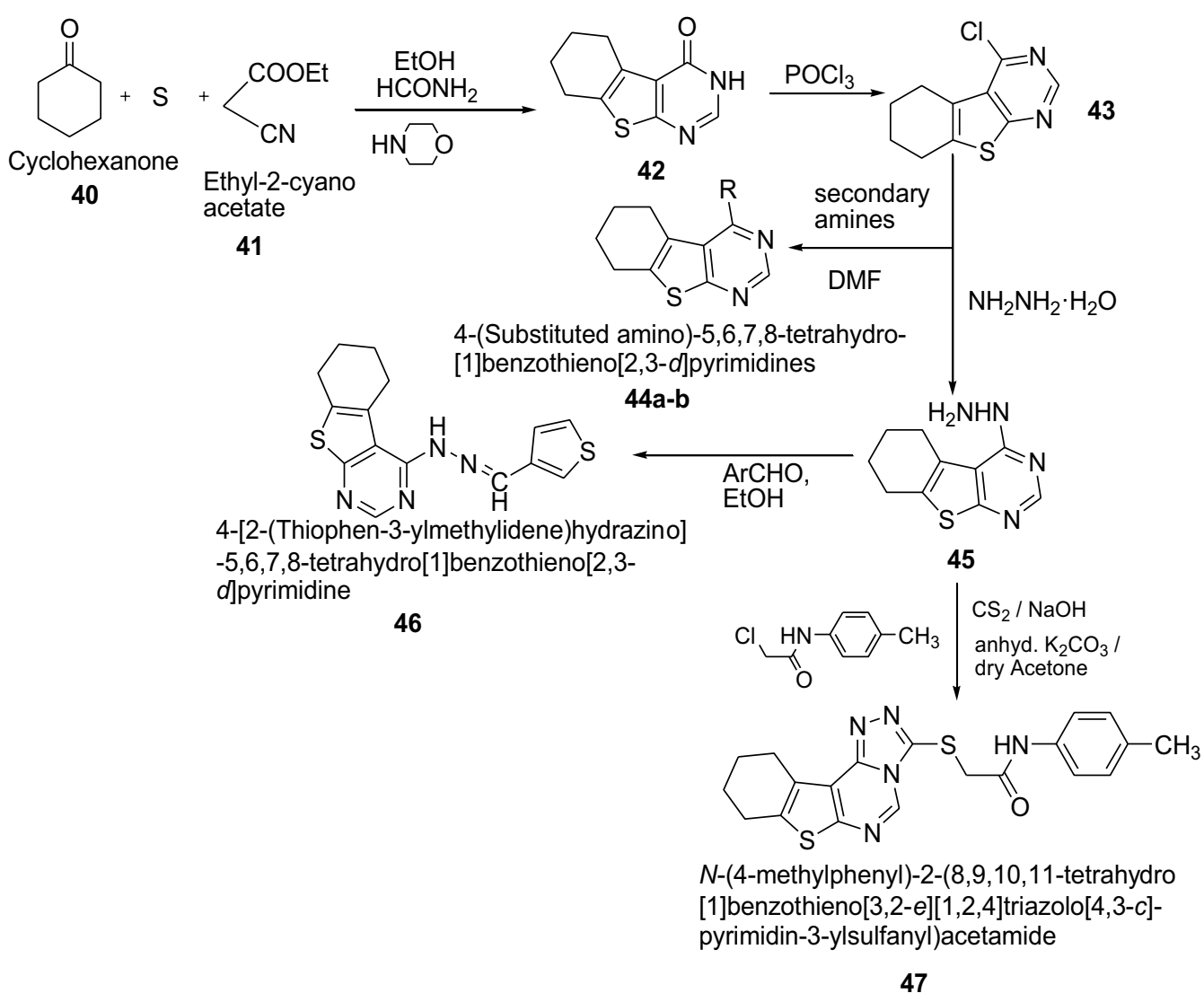

Scheme 9 Synthesis of tetrahydrobenzothieno[2,3-d]pyrimidine and tetrahydrobenzothienotri azolopyrimidine

Table 10 Antibacterial and antifungal activities of synthesized compounds

\begin{tabular}{lllll}
\hline Compound & \multicolumn{4}{l}{ The inhibition zones (IZ) in mm diameter } \\
\cline { 2 - 5 } & S. aureus & E. coli & P. aeruginosa & C. albicans \\
\hline $\mathbf{4 4 a}$ & - & 15 & 16 & 22 \\
$\mathbf{4 4 b}$ & - & 16 & 19 & 16 \\
$\mathbf{4 6}$ & 21 & 17 & 20 & 20 \\
$\mathbf{4 7}$ & - & 17 & - & 22 \\
Ampicillin & 25 & 28 & 32 & - \\
Clotrimazole & - & - & - & 35 \\
\hline
\end{tabular}

(-) no inhibition zone, Minimum Inhibitory Concentrations was expressed as $(\mu \mathrm{g} / \mathrm{ml})$

alternate and C. corchori. The disc diffusion method and poisoned-food techniques were used for antibacterial and antifungal activities, respectively. Among the synthesized compounds 28 and $\mathbf{3 3}$ resulted in wide spectrum antimicrobial activity against all the test bacteria and fungi using ampicillin and nystatin as a standard drug, respectively. Introduction of imidazo (28) or pyrazolo (33) moiety to the pyrimidine derivatives might be responsible for enhancement of antimicrobial activity of these compounds. The results of synthesized compounds are presented in Tables 7 and 8.

Khazi et al. [21] developed some novel tricyclic thienopyrimidines and triazole fused tetracyclic thienopyrimidines derivatives by employing the Gewald reaction (Scheme 8). The synthesized compounds were evaluated against two Gram positive bacteria (S. aureus, B. subtilis), two Gram negative bacteria (P. aeruginosa, E. coli) and two yeast-like fungi $C$. albicans and $C$. parapsilosis using the broth micro dilution method. The result indicated that the compounds 35, 37, 39a, 39b and 39c have exhibited good antibacterial activity against $B$. subtilis comparable to the standard ampicillin, while compound 38 displayed better antifungal activity against $C$. albicans comparable to the standard fluconazole. The results of synthesized compounds are presented in Table 9.

Tombary et al. [22] synthesized series of tetrahydrobenzothieno $[2,3-d]$ pyrimidine and tetrahydrobenzothienotriazolopyrimidine derivatives as presented in Scheme 9 and evaluated for their antimicrobial activity using the cup diffusion technique against S. aureus as Gram-positive bacteria, E. coli and 


$\begin{aligned} & \text { Ethyl 4-amino-5-cyano-2- } \\ & \text { (methylthio)thiophene-3- } \\ & \text { carboxylate } \\ & \text { 49b }\end{aligned}$
Scheme 10

P. aeruginosa as Gram-negative bacteria in addition to $C$. albicans as fungi. The minimum inhibitory concentration (MIC) and minimum bactericidal concentration (MBC) for the active compounds were studied and compared with ampicillin and clotrimazole as reference antibiotics. Antimicrobial testing revealed that compounds $\mathbf{4 4 a}$ and 47 were the most active among the tested compounds against $C$. albicans while compounds $\mathbf{4 4 b}$ and 46 showed the highest antibacterial potency against $P$. aeruginosa among the tested compounds. The significant results of these compounds are presented in Table 10.

Adiwish et al. [23] synthesized tetra substituted thiophenes from ketene dithioacetals as represented in Scheme 10. The synthesized compounds $49 a$ and $49 \mathbf{b}$ were evaluated in vitro for their antibacterial activity against Gram-positive bacteria (S. aureus and B. subtilis) and Gram-negative bacteria (E. coli and K. pneumonia) by using agar disc-diffusion technique. The result revealed that compound 49a exhibited bigger inhibition zones compared to $\mathbf{4 9 b}$. The results of synthesized compounds presented in Table 11.

Reheim et al. [24] synthesized some novel substituted thieno[3,2-c]pyrazole and pyrazolo $\left[3^{\prime}, 4^{\prime}: 4,5\right]$ thieno[2,3d]pyrimidine derivatives as represented in Scheme 11. The antimicrobial activity of the target synthesized compounds were screened against various microorganisms such as E. coli, B. megaterium, B. subtilis, F. proliferatum, T. harzianum, A. niger by the disc diffusion

\section{Table 11 Antibacterial activities of newly synthesized} compounds

\begin{tabular}{lllll}
\hline Bacteria & \multicolumn{4}{l}{ Inhibition zones $(\mathbf{m m})$} \\
\cline { 2 - 5 } & $\mathbf{4 9 a}$ & $\mathbf{4 9 b}$ & DMSO & Streptomycin \\
\hline B. subtilis & - & - & - & 25 \\
S. aureus & 9 & 7 & - & 13 \\
E. coli & 7 & - & - & 25 \\
K. pneumonia & - & - & - & 25 \\
\hline
\end{tabular}

Minimum inhibitory concentrations was expressed as $(\mu \mathrm{g} / \mathrm{ml})$ method. Antibacterial activity result indicated that among the synthesized derivatives, compounds 51, 54 and 56 showed promising broad spectrum antibacterial activities against $E$. coli. The results of synthesized compounds presented in Table 12.

\section{Anticancer activity}

Cancer is among the most challenging health problems worldwide which has become a major problem for increasing mortality rate globally. Currently available treatments such as chemotherapy and radiotherapy can only provide temporary therapeutic benefits as well as being limited by a narrow therapeutic index, remarkable toxicity, and acquired resistance for most of the type of cancer. However, the research of anticancer drugs in the past several decades has shown extensive progress and has cured considerable number of patients. Still it is the extreme area of investigation due to the complex physiological changes in the cell functionality, metastasis and apoptotic mechanisms. Lots of compounds were screened for anticancer activity in the past few years because of the presence of various cell lines and screening methods. Most of the scientist has synthesized and investigated some of novel thiophene derivatives for the anticancer activity carrying the biologically active sulfonamide, isoxazole, benzothiazole, quinoline and anthracene moieties [25-27].

Ghorab et al. [28] developed a novel series of thiophenes derivatives having biologically active sulfonamide, isoxazole, benzothiazole, quinoline and anthracene moieties as presented in Scheme 12. The synthesized compounds were evaluated for in vitro anticancer activity against human breast cancer cell line (MCF7). Many of them showed cytotoxic activities compared to doxorubicin as a positive control. Among this series, (Z)-4-(3-oxo-3(thiophen-2-yl)prop-1-enylamino)- $N$-(thiazol-2-yl)benzenesulfonamide (59), (Z)-4-(3-oxo-3-(thio-phen-2-yl) prop-1-enylamino)- $N$-(1-phenyl-1 $H$-pyrazol-5-yl)benzenesulfonamide (60), (Z)-4-(3-oxo-3-(thiophen-2-yl)prop1-enylamino)- $N$-(pyrimidin-2-yl)benzenesulfonamide 
<smiles>O=C1C(=C2C(=O)N(c3ccccc3)N=C2c2ccccc2)C(c2ccccc2)=NN1O[Ge]</smiles>

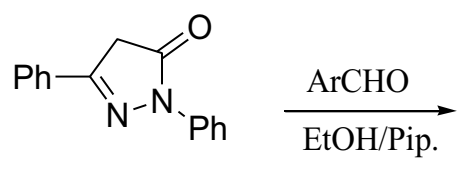

1,3-Diphenyl-1 $H$ pyrazol-5(4H)-one 50 \begin{tabular}{l|l}
$\mathrm{KOH}$ \\
reflux, 20h
\end{tabular}$\stackrel{\mathbf{5 2}}{\left(\mathrm{NH}_{2}\right)_{2} \mathrm{CS}}$

51

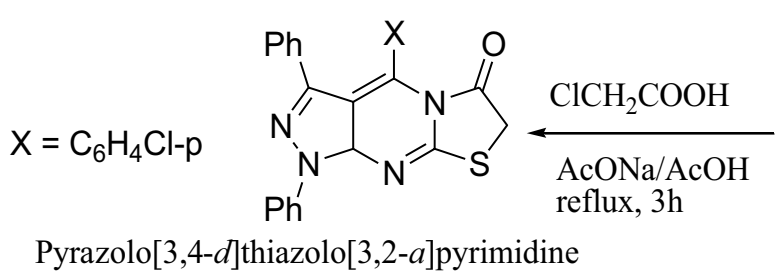<smiles>S=C1NC(Br)=C2C(=NN(c3ccccc3)c3ccccc3)NC12</smiles>

53

54<smiles>NNC(=O)c1c(N)sc2c(-c3ccccc3)nn(-c3ccccc3)c12</smiles>

5-Amino-1,3-diphenyl-1 $H$-thieno [3,2-c]pyrazole-6-carbohydrazide 55<smiles>N#Cc1c(N)n[nH]c1-c1c(N)sc2c(-c3ccccc3)nn(-c3ccccc3)c12</smiles>

3-Amino-5-(5-amino-1,3-diphenyl$1 H$-thieno[3,2-c]pyrazol-6-yl)-1Hpyrazole-4-carbonitrile

\section{6}

Scheme 11 Synthesis of substituted thieno[3,2-c]pyrazole and pyrazolo[ $\left[3^{\prime}, 4^{\prime}: 4,5\right]$ thieno[2,3-d]pyrimidine derivatives

Table 12 Antibacterial and antifungal activities of compound as MIC values $(\mu \mathrm{g} / \mathrm{ml})$

\begin{tabular}{|c|c|c|c|c|c|c|}
\hline \multirow[t]{2}{*}{ Compounds } & \multicolumn{3}{|c|}{ Bacterial species } & \multicolumn{3}{|l|}{ Fungal species } \\
\hline & E. coli & B. megaterium & B. subtilis & F. proliferatum & T. harzianum & A. niger \\
\hline 54 & 15 & 10 & 20 & 12 & 12 & 10 \\
\hline 51 & 20 & 12 & 20 & 12 & 15 & 12 \\
\hline 56 & 15 & 10 & 15 & 20 & 10 & 15 \\
\hline Ampicillin & 23 & 23 & 23 & - & - & - \\
\hline Clotrimazole & - & - & - & 22 & 22 & 22 \\
\hline
\end{tabular}

Inhibition zone diameter ( $\mathrm{mm}$ )

(61) and (Z)-3-(4 methoxybenzo[ $d]$ thiazol-2-ylamino)1-(thiophen-2-yl)prop-2-en-1-one $(\mathbf{6 2})$ having $\mathrm{IC}_{50}$ values $10.25,9.70,9.55$ and $9.39 \mu \mathrm{mol} / \mathrm{l}$, respectively revealed a promising anti-breast cancer activity than that of doxorubicin with $\mathrm{IC}_{50}=32.00 \mu \mathrm{mol} / \mathrm{l}$. It was mainly due to the thiophene nucleus containing biologically active sulfathiazole $\mathbf{5 9}$, sulfaphenazole $\mathbf{6 0}$, sulfadiazine
61, or benzothiazole 62 moieties. The results of synthesized compounds showed in Table 13.

Gaunda et al. [29] synthesized some new derivatives of 3-[(2-substituted-6,7,8,9-tetrahydro-5H-cyclohepta [b] thieno[2,3- $d$ ]pyrimidin-4-yl)amino]propan-1-ol derivatives (Scheme 13). The in vitro cytotoxicity activity of synthesized compounds were screened against both the cell lines (HC 29-Colorectal adenoma cell line and MDA 


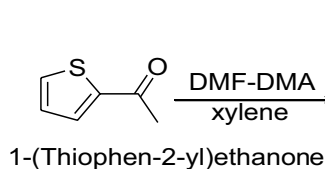

57

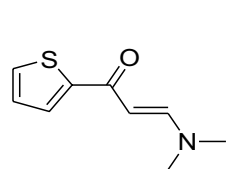

58

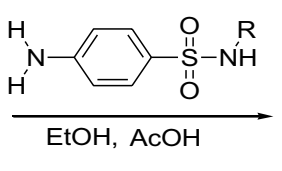

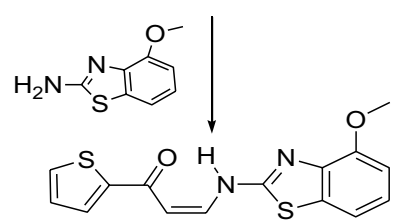

(Z)-3-(4-methoxybenzo[d]thiazol-2-ylamino) -1-(thiophen-2-yl)prop-2-en-1-one

62

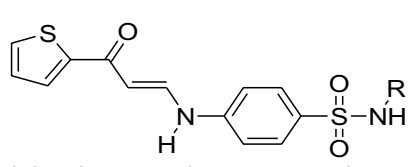

(Z)-4-(3-oxo-3-(thiophen-2-yl)prop-1enylamino)- $N$-(substituted)benzene sulfonamide

59-61

Scheme 12 Synthesis of thiophenes having the biologically active sulfonamide (59-61) and 3-methylisoxazole 12,4-methoxybenzo[d]thiazole (62)

Table 13 In vitro anticancer screening of the newly synthesized compounds against the human breast cancer cell line MCF7

\begin{tabular}{|c|c|c|c|c|c|}
\hline \multirow[t]{3}{*}{ Compound } & \multicolumn{5}{|c|}{ Compound concentration ( $\mu \mathrm{mol} / \mathrm{l})$} \\
\hline & \multicolumn{5}{|c|}{ Surviving fraction ${ }^{a}$} \\
\hline & 10 & 25 & 50 & 100 & $\mathrm{IC}_{50}(\mu \mathrm{mol} / \mathrm{l})$ \\
\hline Doxorubicin & $0.551 \pm 0.026$ & $0.480 \pm 0.003$ & $0.139 \pm 0.005$ & $0.130 \pm 0.016$ & 32.00 \\
\hline 59 & $0.541 \pm 0.003$ & $0.323 \pm 0.020$ & $0.360 \pm 0.018$ & $0.460 \pm 0.015$ & 10.25 \\
\hline 60 & $0.480 \pm 0.010$ & $0.327 \pm 0.016$ & $0.313 \pm 0.005$ & $0.381 \pm 0.007$ & 9.70 \\
\hline 61 & $0.443 \pm 0.017$ & $0.251 \pm 0.012$ & $0.355 \pm 0.020$ & $0.290 \pm 0.009$ & 9.55 \\
\hline 62 & $0.435 \pm 0.009$ & $0.233 \pm 0.006$ & $0.371 \pm 0.018$ & $0.309 \pm 0.011$ & 9.39 \\
\hline
\end{tabular}

a Mean \pm S.E, $n=3$<smiles>O=C1CCCCCC1</smiles>

Cycloheptanoe

63

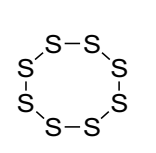

64 4<smiles>CCC(N=[18O])C(=O)O</smiles>

65<smiles>CCOC(=O)c1c(N)sc2c1CCCCC2</smiles>

66

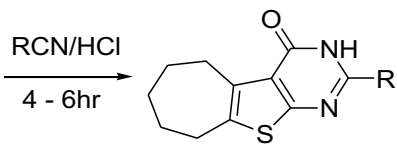

67

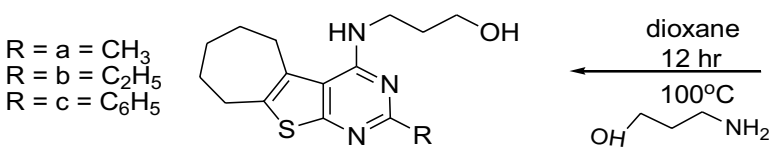<smiles>[R]c1nc(Cl)c2c3c(sc2n1)CCCCC3</smiles>

68

3-[(2-Substituted-6,7,8,9-tetrahydro-5H-cyclohepta [b]thieno[2,3-d] pyrimidin-4-yl)amino]propan-1-ol

69a-c

Scheme 13 Synthesis of 3-[(2-substituted-6,7,8,9-tetrahydro-5H-cyclohepta[b]thieno[2,3-d]pyrimidin-4-yl)amino]propan-1-ol

231-adenocarcinoma breast cancer cell line) by MTT assay and analyzed statistically. Among this series, the compound 69c had shown better anticancer activity at all concentrations on both the cell lines followed by compound 69a, 69b. It was due to the phenyl substitution (69c) which has shown better anticancer activity. 
Table 14 Anticancer activity of the title compounds (69a69c)

\begin{tabular}{|c|c|c|c|}
\hline \multirow{2}{*}{$\begin{array}{l}\text { Compound } \\
\text { code }\end{array}$} & \multirow{2}{*}{$\begin{array}{l}\text { Concentration } \\
(\mu \mathrm{mol})\end{array}$} & \multicolumn{2}{|c|}{ Percentage inhibition of cell growth } \\
\hline & & $\begin{array}{l}\mathrm{HC} \\
29 \text {-colorectal } \\
\text { adenoma cell } \\
\text { line (\%) }\end{array}$ & $\begin{array}{l}\text { MDA } 231- \\
\text { adenocarcinoma } \\
\text { breast cancer cell } \\
\text { line }(\%)\end{array}$ \\
\hline \multirow[t]{3}{*}{$69 a$} & 0.03 & 32.39 & 31.18 \\
\hline & 0.07 & 31.43 & 29.35 \\
\hline & 0.17 & 27.96 & 24.47 \\
\hline \multirow[t]{3}{*}{$69 b$} & 0.03 & 30.73 & 24.94 \\
\hline & 0.07 & 27.94 & 25.79 \\
\hline & 0.17 & 25.27 & 26.41 \\
\hline \multirow[t]{3}{*}{$69 c$} & 0.03 & 34.52 & 33.68 \\
\hline & 0.07 & 32.83 & 30.72 \\
\hline & 0.17 & 28.45 & 25.35 \\
\hline
\end{tabular}

However, all the synthesized compounds showed considerable anticancer activity as compared to cyclophosphamide. The results of synthesized compounds presented in Table 14.

Mohareb et al. [30] developed a convenient synthetic approach for novel thiophene and benzothiophene derivatives (Scheme 14). The in vitro cytotoxicity was screened against three tumor cell lines-MCF-7 (breast adenocarcinoma), NCI-H460 (non-small cell lung cancer) and SF-268 (CNS cancer) and a normal fibroblast human cell line (WI-38) compared to the anti-proliferative effects of the reference control doxorubicin. Among the series, ethyl-5-amino-3-(4-chlorostyryl)-4-cyanothiophene2-carboxylate (74), ethyl 5-amino-4-[(4-methoxyphenyl) carbamoyl]-3-methylthiophene-2-carboxylate and ethyl 5-(3-ethoxy-3-oxopropanamido)-3-methyl-4(phenylcarbamoyl)thiophene-2-carboxylate (77) were found to be the most active compounds against the three tumor cell lines such as MCF-7, NCI-H460 and SF-268 where as they showed low potency against the normal fibroblasts human cell line (WI-38). It was revealed that higher cytotoxicity activity of compound $\mathbf{7 4}$ was due to the presence of the chloro group, $\mathrm{OCH}_{3}$ group in compound $\mathbf{7 6 b}$ and the presence of two ethoxy groups in compound 77. Thus it has been shown that, in most cases, the electronegative $\mathrm{Cl}, \mathrm{OCH}_{3}$ and $\mathrm{OC}_{2} \mathrm{H}_{5}$ hydrophobic groups in the thiophene derivatives might play a very important role in enhancing the cytotoxic effect. The results of synthesized compounds presented in Table 15.

Sharkawy et al. [31] synthesized a series of thiophene incorporating pyrazolone moieties via diazo coupling of diazonium salt of 3-substituted-2-amino-<smiles>[Y]CC#[N+]S[CH]C(C)=O</smiles>

a Synthesis of various derivatives of thiophene

74

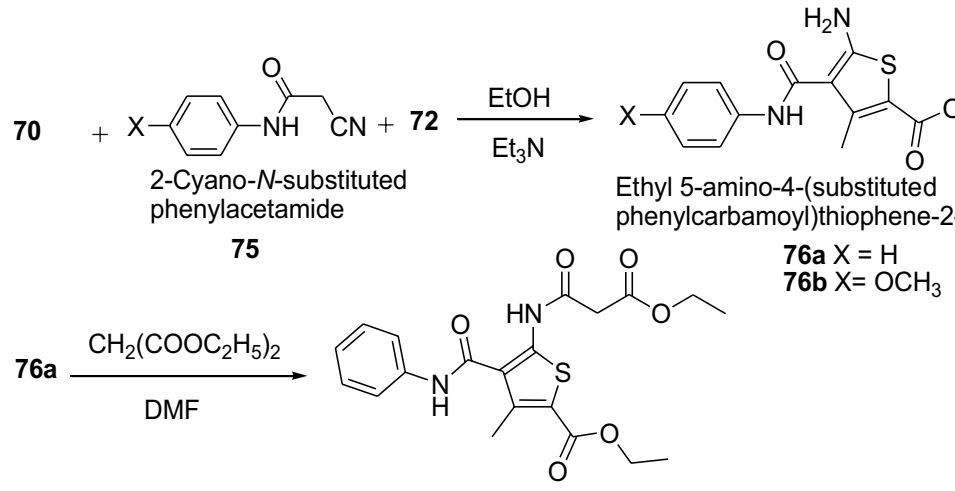

Ethyl 5-(3-ethoxy-3-oxopropanamido)-3-methyl-4(phenylcarbamoyl)thiophene-2-carboxylate

77

b Synthesis of various benzothiophene derivatives

Scheme 14 a Synthesis of various derivatives of thiophene, $\mathbf{b}$ Synthesis of various benzothiophene derivatives 
Table 15 Anticancer activity of the title compounds

\begin{tabular}{|c|c|c|c|c|}
\hline \multirow[t]{2}{*}{ Compound } & \multicolumn{4}{|l|}{$\mathrm{IC}_{50}(\mu \mathrm{mol} / \mathrm{I})^{\mathrm{a}}$} \\
\hline & MCF-7 & $\mathrm{NCl}-\mathrm{H} 460$ & SF-268 & WI-38 \\
\hline 74 & $0.03 \pm 0.007$ & $0.02 \pm 0.008$ & $0.01 \pm 0.004$ & $>100$ \\
\hline $76 b$ & $0.01 \pm 0.006$ & $0.03 \pm 0.002$ & $0.06 \pm 0.005$ & $>100$ \\
\hline 77 & $0.01 \pm 0.003$ & $0.02 \pm 0.001$ & $0.01 \pm 0.001$ & $66.5 \pm 12.7$ \\
\hline DSMO & $94.3 \pm 6.4$ & $96.4 \pm 10.2$ & $98.6 \pm 12.2$ & $>100$ \\
\hline Doxorubicin & $0.0428 \pm 0.0082$ & $0.0940 \pm 0.0087$ & $0.0940 \pm 0.0070$ & $>100$ \\
\hline
\end{tabular}

a Drug concentration required to inhibit tumor cell proliferation by $50 \%$ after continuous exposure of $48 \mathrm{~h}$; data are expressed as mean \pm SEM of three independent experiments performed in duplicates

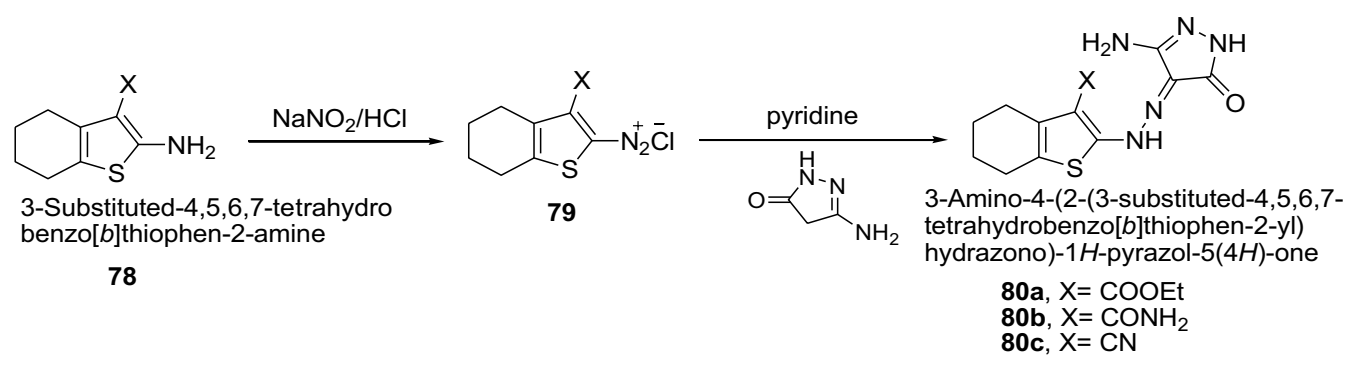

Scheme 15 Synthesis of substituted-4-\{2-[(or 3-phenyl-)4,5,6,7-tetrahydrobenzo[b]thiophen-2-yl]hydrazono\}-1H-pyrazol-5(4H)-one derivatives

Table 16 Antitumor activity of synthesized compounds

\begin{tabular}{llll}
\hline Compound no & \% Dead & \\
\cline { 2 - 4 } & $\mathbf{1 0 0} \boldsymbol{\mu g} / \mathbf{m l}(\%)$ & $\mathbf{5 0 0} \boldsymbol{\mu g} / \mathbf{m l}(\%)$ & $\mathbf{2 5} \boldsymbol{\mu \mathbf { g } / \mathbf { m l } ( \% )}$ \\
\hline 5-Fluorouracil & 97.3 & 68 & 38.6 \\
$\mathbf{8 0 a}$ & 100 & 98.6 & 94 \\
$\mathbf{8 0 b}$ & 98.4 & 81 & 65 \\
$\mathbf{8 0 c}$ & 98.1 & 79 & 60 \\
\hline
\end{tabular}

The $\%$ dead refers to the $\%$ of the dead tumor cells

4,5,6,7-tetrahydrobenzo[b]thiophenes with 3-methyl$1 H$-pyrazol-5(4H)-one, 3-methyl-1-phenyl-1H-pyrazol-5(4H)-one or 3-amino-1H-pyrazol-5(4H)-one, respectively as represented in Scheme 15. Newly synthesized derivatives were tested for cytotoxicity against the well known established model ehrlich ascites carcinoma cells (EAC) in vitro. The results showed clearly that compounds $\mathbf{8 0 a}-\mathbf{c}$ exhibited high cytotoxic activity than 5-fluorouracil which may be due to the presence of amino group in position 3 of the pyrazol-5-one moiety. Further, the order of antitumor activity of this series of synthesized compounds follows $\mathbf{8 0 c}<\mathbf{8 0 b}<\mathbf{8 0 a}$ which may be due to replacement of $\mathrm{CONH}_{2}$ by $\mathrm{CN}$ or $\mathrm{COOC}_{2} \mathrm{H}_{5}$ groups of benzothiophene ring in position 3 . The results of synthesized compounds showed in Table 16.

Seley et al. [32] synthesized tricyclic thieno-separated purine analogues using Scheme 16. These synthesized derivatives were screened for their cytotoxic activity against HCT116 colorectal cancer cell lines.

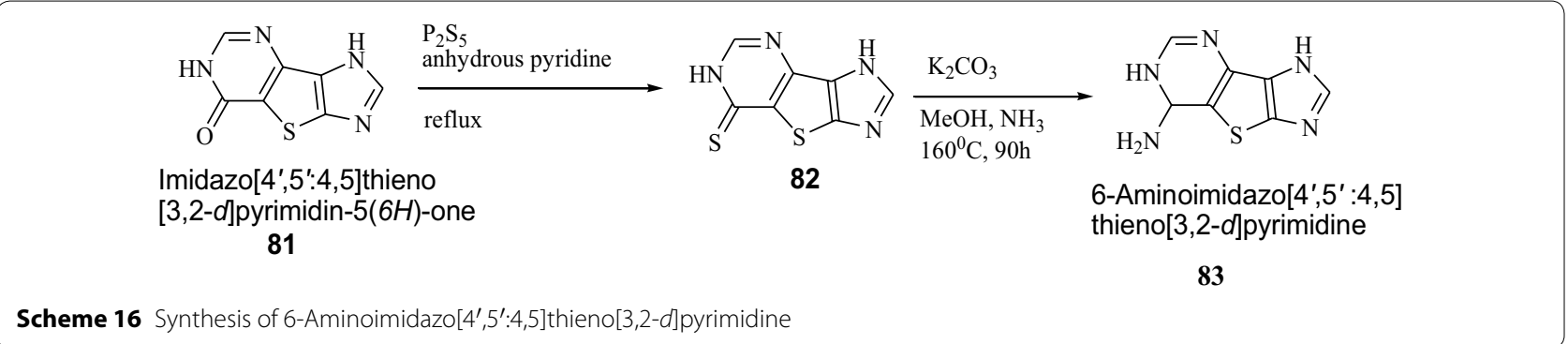


Table 17 Tricyclic of HCT116 growth

\section{compound-induced}

\begin{tabular}{llrrrl}
\hline Time (h) & Compd & \multicolumn{1}{l}{$\mathbf{0 . 1} \boldsymbol{\mu M}$} & \multicolumn{1}{l}{$\boldsymbol{1} \mathbf{M}$} & \multicolumn{1}{l}{$\mathbf{1 0} \boldsymbol{\mu M}$} & $\mathbf{1 0 0} \boldsymbol{\mu M}$ \\
\hline 24 & $\mathbf{8 3}$ & $96.1 \pm 3.8$ & $106.6 \pm 4.8$ & $104.8 \pm 3.8$ & $82.0 \pm 7.8$ \\
48 & $\mathbf{8 3}$ & $105.1 \pm 3.3$ & $98.3 \pm 4.3$ & $105.0 \pm 2.1$ & $71.5 \pm 3.8^{\mathrm{b}}$ \\
72 & $\mathbf{8 3}$ & $101.3 \pm 7.3$ & $96.1 \pm 6.6$ & $93.8 \pm 12.1$ & $51.5 \pm 10.7^{\mathrm{a}}$
\end{tabular}

$\mathrm{HCT} 116$ cells were treated and growth was assessed. Data represent the average (SEM as a \% of control-treated (DMSO) cells $(n=3-5$ )

a $p<0.05$

${ }^{b} p<0.005$ when compared to control-treated cells

In this series, compound $\mathbf{8 3}$ showed potent cytotoxic activity against cancer cell lines. It was due to the coupling of compound $\mathbf{8 3}$ to a ribo-sugar to create the thieno-separated nucleosides may increase the growth inhibitory properties of these analogues. The results of synthesized compounds presented in Table 17.

Mohareb et al. [33] synthesized novel heterocyclic compounds from 2-cyano- $N$-(3-cyano-4,5,6,7tetrahydrobenzo[ $[b]$ thiophen-2-yl)-acetamide as presented in Scheme 17. The tumor cell growth inhibition activities of the newly synthesized thiophene systems were assessed in vitro on three human tumor cell lines, namely, MCF-7 (breast adenocarcinoma), NCIH460 (non-small cell lung cancer), and SF-268 (CNS cancer) after a continuous exposure of $48 \mathrm{~h}$. The results were compared to the antiproliferative effects of the reference control doxorubicin. In this series, compounds $\mathbf{8 9}, \mathbf{8 6}, \mathbf{8 8}, \mathbf{8 5}$, and 87 showed significant activity on the<smiles>N#CCC(=O)Nc1sc2c(c1C#N)CCCC2</smiles><smiles>O=Cc1cccc(O)c1</smiles>

2-Cyano- $N$-(3-cyano-4,5,6,7-tetrahydro benzo[b]thiophen-2-yl)-acetamide

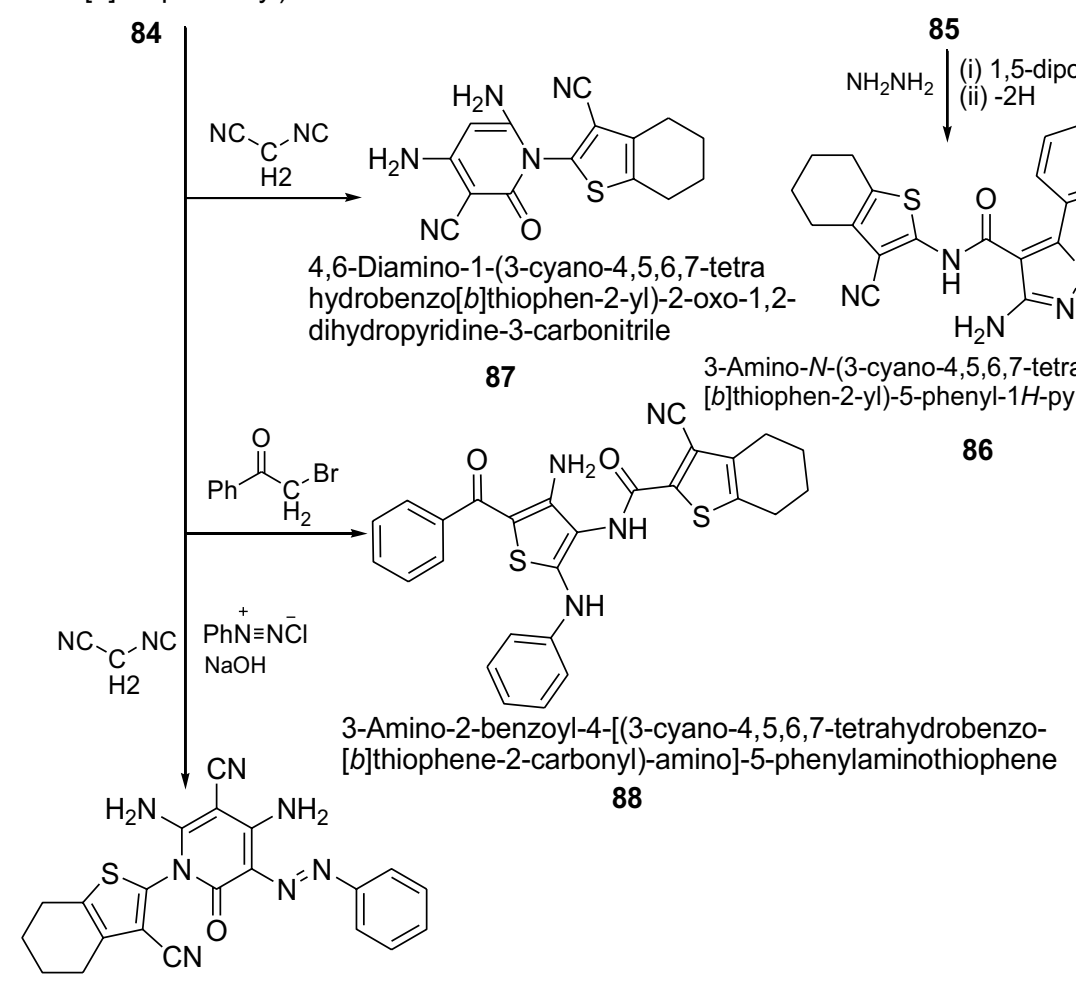<smiles>N#Cc1c(NC(=O)c2cc3ccccc3oc2=O)sc2c1CCCC2</smiles>

$\mathrm{N}$-(3-cyano-4,5,6,7-tetrahydrobenzo[b]thiophen-2-yl) --oxo-2H-chromen-3-il-carboxamide (1) (n)

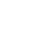




\begin{tabular}{|c|c|c|c|}
\hline \multirow[t]{2}{*}{ Compound } & \multicolumn{3}{|l|}{$\mathrm{GI} 50(\mu \mathrm{M})^{\mathrm{a}}$} \\
\hline & MCF-7 & $\mathrm{NCl}-\mathrm{H} 460$ & SF-268 \\
\hline 85 & $10.8 \pm 0.6$ & $16.5 \pm 0.8$ & $16.7 \pm 1.6$ \\
\hline 86 & $2.5 \pm 0.5$ & $10.4 \pm 0.6$ & $8.0 \pm 0.4$ \\
\hline 87 & $16.7 \pm 1.6$ & $10.8 \pm 0.6$ & $16.5 \pm 0.8$ \\
\hline 88 & $11.8 \pm 0.6$ & $14.5 \pm 0.8$ & $16.7 \pm 1.6$ \\
\hline 89 & $2.0 \pm 0.4$ & $8.3 \pm 0.8$ & $4.0 \pm 0.8$ \\
\hline Doxorubicin & $0.0428 \pm 0.0082$ & $0.0940 \pm 0.0087$ & $0.0940 \pm 0.0070$ \\
\hline
\end{tabular}

a Drug concentration required to inhibit tumor cell proliferation by $50 \%$ after continuous exposure of $48 \mathrm{~h}$. Doxorubicin was used as positive control

three tumor cell lines tested. The results of synthesized compounds showed in Table 18.

\section{Antioxidant activities}

Madhavi et al. [34] developed a novel class of substituted 2-(2-cyanoacetamido)thiophenes by cyanoacetylation of substituted 2-aminothiophene by using an effective cyanoacetylating agent, 1-cyanoacetyl3,5-dimethylpyrazole as presented in Scheme 18. All the synthesized compounds were evaluated for in vitro antioxidant activity by scavenging 1,1-diphenyl-2-picrylhydrazyl (DPPH) and nitric oxide free radicals at $100 \mu \mathrm{M}$ concentration. Among these evaluated compounds, 2-(2-cyanoacetamido)-4,5-dimethylthiophene-3-carboxamide (Compound 92a) was found to possess highest anti-oxidant activity in both models of free radical scavenging. However in case of assay with nitric oxide free radical scavenging, the highest activity was exhibited by 2-(2-cyanoacetamido)-4,5-dimethylthiophene-3-carboxamide (Compound 92a, 56.9\%) and 2-(2-cyanoacetamido)-4,5,6,7-tetrahydrobenzo $[b]$ thiophene-3-carboxamide (Compound 92b, 55.5\%). The greater activity of these compounds were attributed due to the polar nature of carboxamide or nitrile group at 3rd position on thiophene ring. The results of synthesized compounds presented in Tables 19 and 20.

\begin{tabular}{lccc}
$\begin{array}{l}\text { Table } 19 \text { Reduction } \\
\text { 2-(2-cyanoacetamido) thiophenes }\end{array}$ & $\begin{array}{c}\text { of } \\
\text { Compound }\end{array} \mathbf{R}_{\mathbf{1}}, \mathbf{R}_{\mathbf{2}}$ & $\mathbf{R}_{\mathbf{3}}$ & substituted \\
\hline & & $\begin{array}{l}\% \\
\text { Inhibition } \\
\text { at } 100 \boldsymbol{\mu M}\end{array}$ \\
\hline 92a & $-\mathrm{CH}_{3}$ & $-\mathrm{CONH}_{2}$ & 52.4 \\
Ascorbic acid & & & 64.7 \\
\hline
\end{tabular}

Table 20 Effect of substituted 2-(2-cyanoacetamido) thiophenes on scavenging of nitric oxide

\begin{tabular}{llll}
\hline Compound & $\mathbf{R}_{\mathbf{1}}, \mathbf{R}_{\mathbf{2}}$ & $\mathbf{R}_{\mathbf{3}}$ & $\begin{array}{l}\% \\
\text { Inhibition } \\
\text { at } \mathbf{1 0 0} \boldsymbol{\mu M}\end{array}$ \\
\hline $\mathbf{9 2 a}$ & $-\mathrm{CH}_{3}$ & $-\mathrm{CONH}_{2}$ & 56.9 \\
$\mathbf{9 2 \mathbf { b }}$ & $-\left(\mathrm{CH}_{2}\right)_{4}-$ & $-\mathrm{CONH}_{2}$ & 55.5 \\
\hline
\end{tabular}

\section{Anti-inflammatory activity}

Bahashwan et al. [35] synthesized new series of fused triazolo- and tetrazolopyrimidine derivatives (Scheme 19) and their anti-inflammatory activity was evaluated. Newly synthesized thienopyrimidine derivatives were screened for anti-inflammatory activity (percent inhibition of edema obtained by the reference drug and tested compounds, respectively) in comparison to that of indomethacin. Among the series, compounds 94, 95, 96, 97 and 98 possess strong anti-inflammatory activity. The high anti-inflammatory activity was mainly due to the presence of electron-donating moieties which increase the pharmacological activity. The order of anti-inflammatory properties with the substitution of electron-donating group in pyrimidine derivatives follows as: hydrazine $>$ methyl $>$ cyanomethyl $>$ tetrazine $>$ amide as exhibited in compounds 94 $>98>95>96>97$, respectively. The results of synthesized compounds presented in Table 21.

Ouf et al. [36] synthesized hydrazones derivatives which shows significant anti-inflammatory activities as presented in Scheme 20. The synthesized compounds<smiles>[R]c1sc(N)c([R])c1[R]</smiles>

3-(3,5-Dimethyl-1H-pyrazol1-yl)-3-oxopropanenitrile 90<smiles>[R]c1sc(NC(=O)CC)c([R])c1[R]</smiles>

Substituted 2-(2-cyano acetamido)thiophene 92a-b 


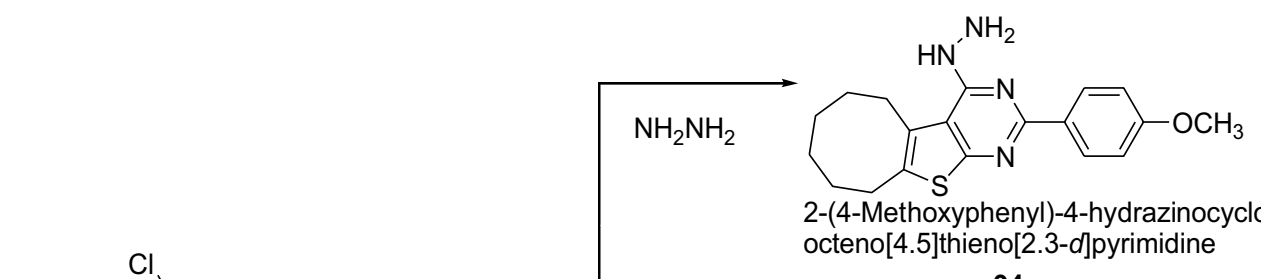

94<smiles>COc1ccc(-c2nc(C)c3c4c(sc3n2)CCCCCC4)cc1</smiles>

2-(4-Methoxypheyl)-4-chlorocycloocteno $[4,5]$ thieno[2,3-e]pyrimidine

93<smiles>COc1ccc(-c2nc3sc4c(c3c3nnc(CC#N)n23)CCCCCC4)cc1</smiles>

5-(4-Methoxyphenyl)-3-cyanomethylcyclo octeno[4.5]thieno[2.3-d] triazolo[1,2,4] -[4,5-a]pyrimidine

95

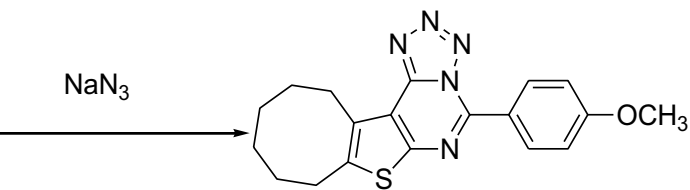

94 thieno[2.3- $d$ ] tetrazolo[4.5-e]pyrimidine 9496

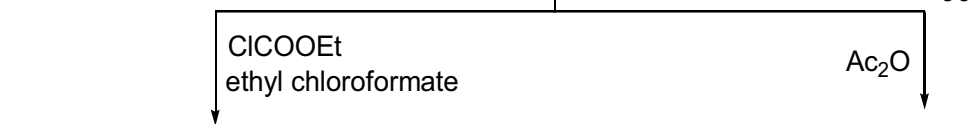

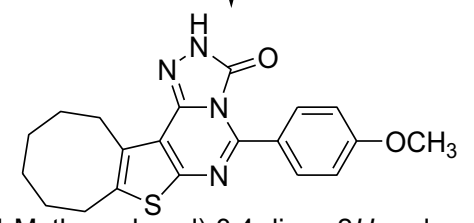

6-(4-Methoxyphenyl)-3,4-dioxo-2H-cycloocteno

[4.5]thieno[2,3- $d$ ] triazino[1,2.4]-[3,4-a]pyrimidine

97<smiles>COc1ccc(-c2nc3sc4c(c3c3nnc(C)n23)CCCCCC4)cc1</smiles>

5-(4-Methoxyphenyl)-3-methyl-2H-cycloocteno $[4,5]$ thieno[2,3- $d][1,2,4]$ triazolo-[4,5-a] pyrimidine

98

Scheme 19 Synthesis of thienotriazolopyrimidine derivatives

Table 21 Anti-inflammatory activity of the synthesized compounds

\begin{tabular}{llll}
\hline Compounds & \multicolumn{3}{l}{ Edema inhibition (means \pm E.M) $\mathbf{a}, \mathbf{b}$} \\
\cline { 2 - 4 } & $\mathbf{1} \mathbf{h}$ & $\mathbf{2} \mathbf{h}$ & $\mathbf{3} \mathbf{~}$ \\
\hline $\mathbf{9 4}$ & $42.3 \pm 1.1$ & $49.2 \pm 1.2$ & $57.1 \pm 1.4$ \\
$\mathbf{9 5}$ & $37.2 \pm 1.3$ & $46.3 \pm 1.5$ & $54.4 \pm 1.1$ \\
$\mathbf{9 6}$ & $34.5 \pm 1.2$ & $35.1 \pm 1.5$ & $48.2 \pm 1.2$ \\
$\mathbf{9 7}$ & $31.2 \pm 1.2$ & $35.1 \pm 1.5$ & $40.2 \pm 1.6$ \\
$\mathbf{9 8}$ & $39.1 \pm 1.5$ & $48.4 \pm 1.2$ & $55.6 \pm 1.1$ \\
Indomethacin & $44.7 \pm 1.2$ & $52.4 \pm 1.2$ & $61.2 \pm 1.3$ \\
\hline
\end{tabular}

a Dose $5 \mathrm{mg} / \mathrm{kg}$ b.m (p.o.)

b $\mathrm{n}=6$ were screened against the standard drug flurbiprofen. Among the synthesized hydrazones, the substituted 4-methoxy- 100a, 4-chloro- 100b and 4-nitro-derivatives 100c have anti-inflammatory activities higher than that of hydrazone with an unsubstituted benzaldehyde group against the standard drug flurbiprofen. Thus, the lipophilicity plays an important role for the potent anti-inflammatory activity. The results of synthesized compounds presented in Table 22.

Hafez et al. [37] synthesized some of the novel benzothino-pyrimidine derivatives (Scheme 21) which showed considerable potent anti-inflammatory activity. The anti-inflammatory activity of the newly synthesized 


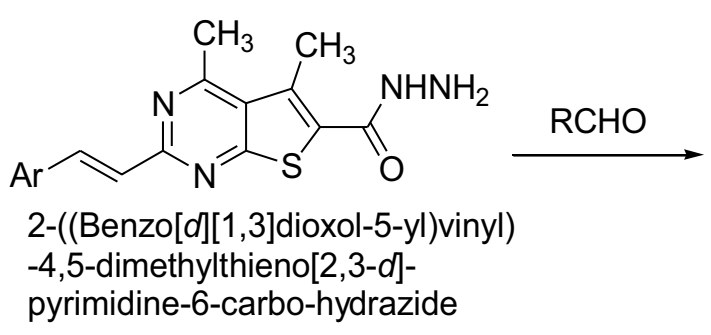

99

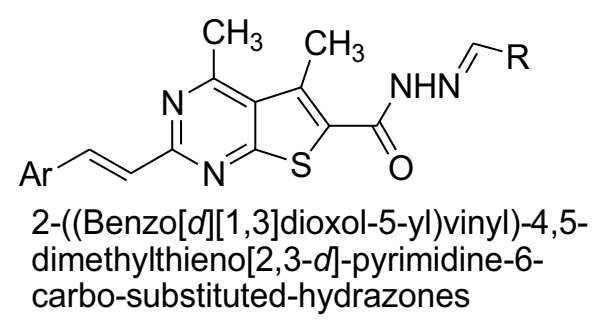

$100 \mathrm{a}=\mathrm{R}=\mathrm{MeOC}_{6} \mathrm{H}_{4}$ $100 \mathrm{~b}=\mathrm{R}=\mathrm{ClC}_{6} \mathrm{H}_{4}$ $100 \mathrm{c}=\mathrm{R}=\mathrm{NO}_{2} \mathrm{C}_{6} \mathrm{H}_{4}$

Scheme 20 Synthesis of 2-((Benzo[d] [1,3] dioxol-5-yl)vinyl)-4,5-dimethylthieno[2,3-d]-pyrimidine-6-carbohydrazones derivatives

Table 22 Anti-inflammatory activity of some synthesized compounds (\% reduction in edema induced by yeast)

\begin{tabular}{lll}
\hline Compound & Post treatment $\mathbf{3} \mathbf{h}=\%$ & Post treatment $\mathbf{6} \mathbf{h =} \%$ \\
\hline $\mathbf{1 0 0 a}$ & 26.6 & 34.4 \\
$\mathbf{1 0 0 b}$ & 17.2 & 30.0 \\
100c & 24.2 & 34.2 \\
\hline
\end{tabular}

compounds were evaluated by applying carrageenaninduced paw edema bioassay in rats using indomethacin as a reference standard. Compounds 105, 106, 107, 108 and 109 caused significant decreases in paw edema after 2, 3, $4 \mathrm{~h}$ after drug administration. Thus, it can be concluded that spirobenzothienopyrimidine moiety, phenylpyrazolothinopyrimidine, morphonyl and piperazinylthinopyrimidine ring systems are important for

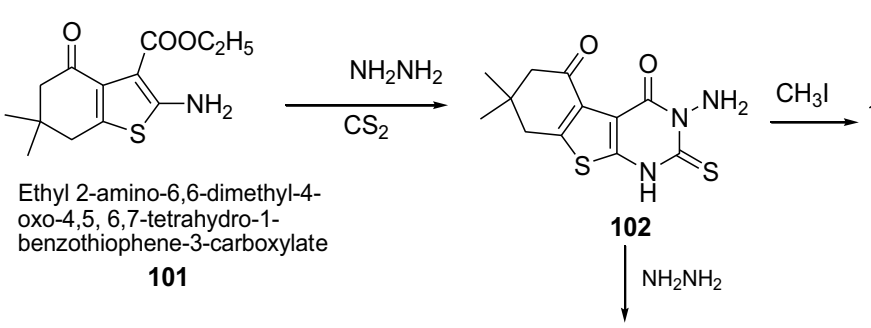<smiles>CSC1Nc2sc3c(c2C(=O)N1N)C(=O)CC(C)(C)C3</smiles>

3-Amino-7,7-dimethyl-2-(methylthio)-

3,6,7,8-tetrahydro[1]benzothieno

$[2,3-d]$ pyrimidine-4,5-dione

103

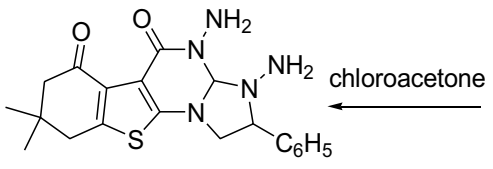

3,4-Diamino-8,8-dimethyl-2-phenyl-3a,4,8 9-tetrahydro[1]benzothieno[3,2-e]imidazo [1,2-a] pyrimidine-5,6- $(3 H, 7 H)$-dione

105<smiles>CC1(C)CC(=O)c2c(sc3c2C(=O)N(N)C(NN)N3)C1</smiles>

104<smiles>Cc1nn(C2Nc3sc4c(c3C(=O)N2N)C(=O)CC(C)(C)C4)c(C)c1Cl</smiles>

3-Amino-2-(4-chloro-3,5-dimethyl-1Hpyrazol-1-yl)-7,7-dimethyl-3,6,7,8tetrahydro[1] benzothieno[2,3- $d$ ] pyrimidine-4,5-dione

106
$\sqrt{\mathrm{HN}} \mathrm{NH}$<smiles>CC1(C)CC(=O)c2c(sc3c2C(=O)N(N)C(N2CCOCC2)N3)C1</smiles>

3-amino-7,7-dimethyl-2-morpholin-4-yl3,6,7,8-tetrahydro[1]benzothieno[2,3-d] pyrimidine-4,5-dione

$$
107
$$

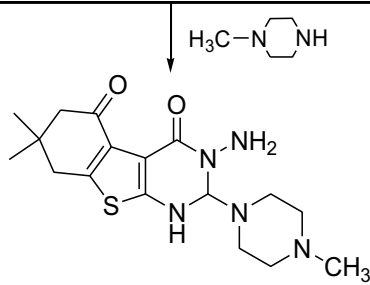

3-amino-7,7-dimethyl-2-(4-methy piperazin-1-yl)-3,6,7,8-tetrahydro [1]benzo-thieno[2,3-d]pyrimidine -4,5-dione

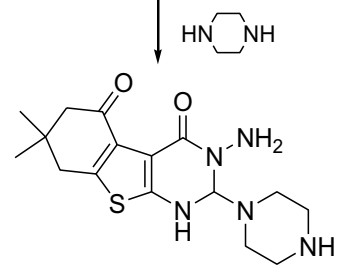

3-amino-7,7-dimethyl-2-piperazin-1-yl)

-3,6,7,8-tetraahydro[1]benzothieno

$[2,3-d]$ pyrimi-dine-4,5-dione

109

Scheme 21 Synthesis of phenylpyrazolothinopyrimidine, morphonyl and piperazinylthinopyrimidine derivatives 
Table 23 Anti-inflammatory effect of synthesized compounds

\begin{tabular}{lllll}
\hline Compd. no. & \multicolumn{4}{l}{ Oedema volume } \\
\cline { 2 - 5 } & $\mathbf{1 ~ h}$ & $\mathbf{2} \mathbf{~}$ & $\mathbf{3} \mathbf{~}$ & $\mathbf{4} \mathbf{~}$ \\
\hline $\mathbf{1 0 5}$ & $49.4 \pm 7.1$ & $71.8 \pm 6.7^{\mathrm{a}}$ & $76.4 \pm 4.8^{\mathrm{a}}$ & $82.2 \pm 5.2$ \\
$\mathbf{1 0 6}$ & $44.2 \pm 5.1$ & $59.6 \pm 4.7^{\mathrm{a}}$ & $67.8 \pm 3.3^{\mathrm{a}}$ & $81.9 \pm 3.2$ \\
$\mathbf{1 0 7}$ & $61.0 \pm 6.6$ & $66.6 \pm 5.9^{\mathrm{a}}$ & $68.6 \pm 7.0^{\mathrm{a}}$ & $72.4 \pm 7.4$ \\
$\mathbf{1 0 8}$ & $66.4 \pm 7.5$ & $78.2 \pm 3.5^{\mathrm{a}}$ & $81.3 \pm 3.3$ & $87.1 \pm 2.1$ \\
$\mathbf{1 0 9}$ & $56.2 \pm 9.9$ & $65.1 \pm 7.5^{\mathrm{a}}$ & $55.9 \pm 10.6^{\mathrm{a}}$ & $54.7 \pm 7.2^{\mathrm{a}}$ \\
Indomethacin & $49.8 \pm 5.3$ & $42.9 \pm 5.1^{\mathrm{a}}$ & $45.9 \pm 4.6^{\mathrm{a}}$ & $46.9 \pm 5.8^{\mathrm{a}}$ \\
\hline
\end{tabular}

a $p<0.05$ : Statistically significant from the control using one way ANOVA (Twosided Dunnett as Post Hoc test)

anti-inflammatory activity. The results of synthesized compounds presented in Table 23.

\section{Antiurease activity}

Rasool et al. [38] synthesized variety of novel 5-aryl thiophenes derivatives containing sulphonylacetamide (sulfacetamide) using Scheme 22. The synthesized compounds were screened for their anti-urease activities by taking thiourea as standard drug. Among all the synthesized derivatives, compound 112, $N$-( (5'-methyl-[2,2'bithiophen]-5-yl)sulfonyl)acetamide, showed excellent urease inhibition activity at $40 \mu \mathrm{g} / \mathrm{ml}$ and $80 \mu \mathrm{g} / \mathrm{ml}$ concentrations where the percentage inhibition values were found to be $92.12 \pm 0.21$ and $94.66 \pm 0.11$, respectively with an $\mathrm{IC}_{50}$ value $\sim 17.1 \pm 0.15 \mu \mathrm{g} / \mathrm{ml}$. It is further concluded that the urease inhibitory activity of compound might be due to the presence of the electronic and steric effects of functional groups. The results of synthesized compounds are presented in Table 24.

\section{Anticonvulsant activity}

Dashyan et al. [39] synthesized 2,4-disubstituted pyr ano $\left[4^{\prime \prime}, 3^{\prime \prime}: 4^{\prime}, 5^{\prime}\right]$ pyrido $\left[3^{\prime}, 2^{\prime}: 4,5\right]$ thieno[3,2- $\left.d\right]$ pyrimidines derivatives by using Scheme 23. The synthesized compounds were screened for the anticonvulsant activity of by taking the comparator drug, diazepam which was performed using male albino mice weighing 18-24 g (200 animals) and rats (Wistar) weighing 120-140 g (40 animals of both sexes).

The anticonvulsant activity of the compounds was assessed by the prevention of clonic twitches and the clonic component of convulsions caused by subcutaneous administration of $90 \mathrm{mg} / \mathrm{kg}$ metrazol in mice. When studying anticonvulsant activity, it was found that the compounds (114a, b, c) and (115a, b, c, d, e) caused a marked protective anticonvulsive effect, which developed in mice starting with a dose of $25 \mathrm{mg} / \mathrm{kg}$, while statistically calculated dose $\left(\mathrm{ED}_{50}\right)$ ranged from 23 to $56 \mathrm{mg} / \mathrm{kg}$ (Table 25).

\section{Antithrombotic activity}

Jubair et al. [40] synthesized novel series of 2-(bromomethyl)-5-aryl-thiophenes derivatives via Suzuki cross-coupling reactions of various aryl boronic acids with 2-bromo-5 (bromomethyl)thiophene as given in Scheme 24. The synthesized compounds were screened for their antithrombolytic activity. All the Compounds $(100 \mu \mathrm{L})$ having concentration of $1 \mathrm{mg} / \mathrm{ml}$ were added to

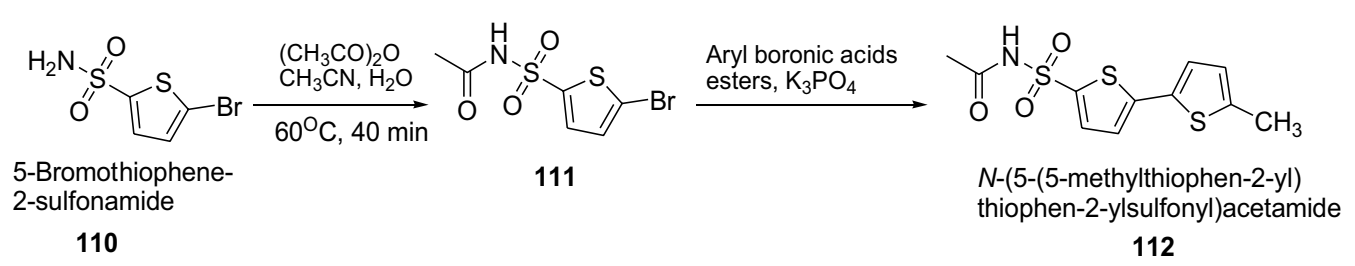

Scheme 22 Synthesis of N-(5-(5-methylthiophen-2-yl)thiophen-2 ylsulfonyl)acetamide

Table 24 Urease inhibition studies of 5-arylthiophene-2-sulfonylacetamides

\begin{tabular}{|c|c|c|c|c|}
\hline Compound & Percentage activity at $15 \mu \mathrm{g} / \mathrm{ml}$ & Percentage activity at $40 \mu \mathrm{g} / \mathrm{ml}$ & Percentage activity at $80 \mu \mathrm{g} / \mathrm{ml}$ & $\mathrm{IC}_{50} \mu \mathrm{g} / \mathrm{ml}$ \\
\hline 112 & $42.44 \pm 0.11$ & $92.12 \pm 0.21$ & $94.66 \pm 0.11$ & $17.1 \pm 0.15$ \\
\hline Standard & $47.1 \pm 0.31$ & $65 \pm 0.01$ & - & $23.3 \pm 0.21$ \\
\hline
\end{tabular}

Standard = Thiourea 
<smiles>CSc1nc(Cl)c2sc3nc(N4CCOCC4)c4c(c3c2n1)CC(C)(C)OC4</smiles>

8-Chloro-2,2-dimethyl-10-methylthio-5-(morpholin4-yl)-1,4-dihydro-2H-pyrano[4",3":4',5']pyrido$\left[3^{\prime}, 2^{\prime}: 4,5\right]$ thieno[3,2- $\left.d\right]$ pyrimidine<smiles>[R]c1nc([SiH3])nc2c1sc1nc(N3CCOCC3)c3c(c12)CC(C)(C)OC3</smiles>

(a), $\mathrm{R}=\left(\mathrm{CH}_{2}\right)_{2} \mathrm{CH}\left(\mathrm{CH}_{3}\right)_{2}$

(b), $\mathrm{R}=\left(\mathrm{CH}_{2}\right)_{3} \mathrm{COCH}_{3}$

(c), $\mathrm{R}=\left(\mathrm{CH}_{2}\right)_{3} \mathrm{COOC}_{2} \mathrm{H}_{5}$<smiles>[R]N([R])c1nc([Si])nc2c1sc1nc(N3CCOCC3)c3c(c12)CC(C)(C)OC3</smiles>

(115à-e)

(a), $\mathrm{R}_{1}=\mathrm{H}, \mathrm{R}_{2}=\left(\mathrm{CH}_{2}\right)_{2} \mathrm{CH}\left(\mathrm{CH}_{3}\right)_{2}$

(b), $\mathrm{R}_{1}=\mathrm{H}, \mathrm{R}_{2}=\left(\mathrm{CH}_{2}\right)_{2} \mathrm{~N}\left(\mathrm{C}_{2} \mathrm{H}_{5}\right)_{2}$

(c), $\mathrm{R}_{1}=\mathrm{H}, \mathrm{R}_{2}=\left(\mathrm{CH}_{2}\right)$-tetrahydrofuran

(d), $\mathrm{R}_{1}=\mathrm{H}, \mathrm{R}_{2}=\mathrm{CH}_{2}$-furan

(e), $R_{1}=R_{2}=4$-ethanolpiperazin

Scheme 23 Synthesis of 2,4-Disubstituted pyrano[ $\left[4^{\prime}, 3^{\prime}: 4,5\right]$ pyrido[2,3-b]thieno[3,2-d]pyrimidine derivatives

\begin{tabular}{|c|c|}
\hline Compound & $\begin{array}{l}\text { Activity against metrazol } \\
\text { convulsions* }(E D 50, \mathrm{mg} / \mathrm{kg})\end{array}$ \\
\hline $114 a$ & $56.0(36.0-100.8)$ \\
\hline $114 b$ & $40.0(23.5-68.0)$ \\
\hline $114 c$ & $23.0(15.9-33.1)$ \\
\hline $115 a$ & $40.0(23.5-68.0)$ \\
\hline $115 b$ & $56.0(36.0-100.8)$ \\
\hline $115 c$ & $34.0(25.3-45.7)$ \\
\hline $115 d$ & $40.0(23.5-68.0)$ \\
\hline $115 e$ & $56.0(36.0-100.8)$ \\
\hline Diazepam & $0.51(0.39-0.69)$ \\
\hline
\end{tabular}

* Probability levels at $p=0.05$ are indicated in brackets
Table 26 Percentage efficiency of Clot lysis of synthetic compounds

\begin{tabular}{ll}
\hline Compounds & Clot lysis \% \\
\hline $\mathbf{1 1 8}$ & $31.5 \pm 0.45$ \\
Water & $0.43 \pm 0.005$ \\
Streptokinase & $87.2 \pm 0.95$ \\
\hline
\end{tabular}

The results are average \pm S.D of triplicate experiments $p<0.05$

the micro-centrifuge tubes containing venous blood, and incubated at $37{ }^{\circ} \mathrm{C}$ for $45 \mathrm{~min}$. Streptokinase was used as standard clot lysis agent and water as negative control for this assay. Among all the synthesized compounds, 118 showed potent clot lysis (31.5\%). However, the results were significant $\mathrm{p}<0.05$, when compared with streptokinase. Clot lysis activity results are presented in Table 26.

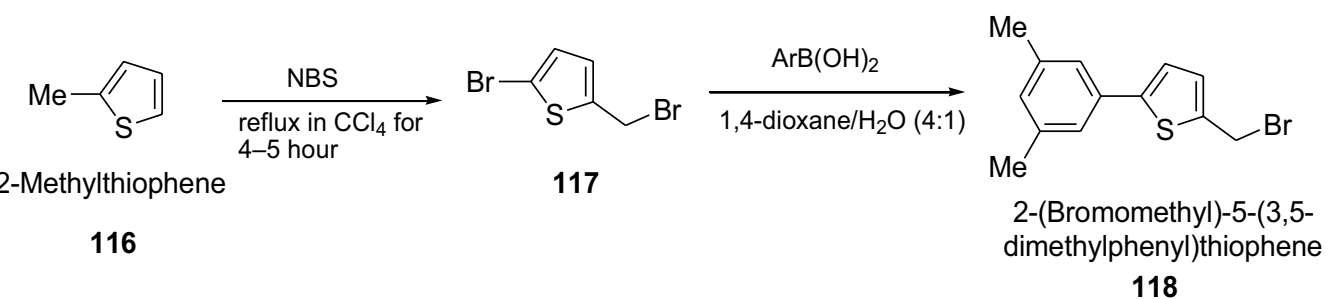

118

Scheme 24 Synthesis of 2-(Bromomethyl)-5-(3,5-dimethylphenyl)thiophene 


\section{Conclusion}

The analytical and other informational data, available in literature so far, have reveals that thiophene and its derivatives represent an important class of compounds in the medicinal field with various therapeutic potentials, i.e., antimalarial, antimicrobial, antimycobacterial, antidepressant, anticonvulsant, antiviral, anticancer, antihypertensive, anti-inflammatory and antioxidant. Appraisal of literature reports reveals that thiophene moiety have hiked a great deal of interests of medicinal chemist and biochemist to plan, organize and implement new approaches towards discovery of novel drugs.

This particular review article, established the fact that thiophene derivatives could be a rich source of potential entities in search of new generation of biologically active compounds and be worthwhile to explore the possibility in this area by fusing differently substituted moieties which may result in better pharmacological activities. Thus the quest to explore many more modifications on thiophene moiety needs to be continued.

\section{Authors' contributions}

PKV designed and finalized the scheme; RS performed review work and wrote the paper. Both authors read and approved the final manuscript.

\section{Acknowledgements}

Thanks to Head, Department of Pharmaceutical Sciences, MD. University, Rohtak for kind support for providing internet facilities etc.

\section{Competing interests}

The authors declare that they have no competing interests.

\section{Ethics approval and consent to participate} Not applicable.

\section{Publisher's Note}

Springer Nature remains neutral with regard to jurisdictional claims in published maps and institutional affiliations.

Received: 4 March 2018 Accepted: 4 December 2018 Published online: 19 December 2018

\section{References}

1. Patel AA, Mehta AG (2010) Synthesis of novel heterocyclic compounds and their biological evaluation. Der Pharm Chem 2(1):215-223

2. Mishra R, Jha KK, Kumar S, Tomer I (2011) Synthesis, properties and biological activity of thiophene: a review. Der Pharm Chem 3(4):38-54

3. Chaudhary A, Jha KK, Kumar S (2012) Biological diversity of thiophene: a review. J Adv Sci Res 3(3):03-10

4. Mishra R, Sharma PK (2015) A review on synthesis and medicinal importance of thiophene. Int J Eng Al Sci 1(1):46-59

5. Chambhare RV, Khadse BG, Bobde AS (2003) Synthesis and preliminary evaluation of some $\mathrm{N}$-[5-(2-furanyl)-2-methyl-4-oxo-4H-thieno[2,3-d] pyrimidin-3-yl]-carboxamide and 3-substituted-5-(2-furanyl)-2-methyl$3 \mathrm{H}$-thieno[2,3-d]pyrimidin-4-ones as antimicrobial agents. Euro J Med Chem 38(1):89-100

6. Tehranchian S, Akbarzadeh T, Fazeli MR, Jamalifar H, Shafiee A (2005) Synthesis and antibacterial activity of 1-[1,2,4-triazol-3-yl] and 1-[1,3,4-thiadiazol-2-yl]-3-methylthio-6,7-dihydro-benzo[c]thiophen4(5H)ones. Bioorg Med Chem Lett 15:1023-1025
7. Pillai AD, Rathod PD, Xavier FP, Pad H, Sudarsanam V, Vasu KK (2005) Tetra substituted thiophenes as anti-inflammatory agents: exploitation of analogue-based drug design. Bioorg Med Chem 13:6685-6692

8. Russell RK, Press JB, Rampulla RA, McNally JJ, Falotico R, Keiser JA, Bright DA, Tobia A (1988) Thiophene systems: thienopyrimidinedione derivatives as potential antihypertensive agents. J Med Chem 31:1786-1793

9. Chen Z, Ku TC, Seley KL (2015) Thiophene-expanded guanosine analogues of gemcitabine. Bioorg Med Chem Lett 25:4274-4276

10. Benabdellah M, Aouniti A, Dafali A, Hammouti B, Benkaddour M, Yahyi A, Ettouhami A (2006) Investigation of the inhibitive effect of triphenyltin2-thiophene carboxylate on corrosion of steel in $2 \mathrm{M} \mathrm{H3PO4} \mathrm{solutions.}$ Appl Surf Sci 252:8341-8347

11. Kim C, Choi KS, Oh JH, Hong HJ, Han SH, Kim SY (2015) The effects of octylthiophene ratio on the performance of thiophene based polymer light-emitting diodes. Sci Adv Mater 7:2401-2409

12. Mishra R, Jha KK, Kumar S, Tomer I (2012) Thiophene: the molecule of diverse medicinal importance. J Pharm Res 5(1):560-566

13. Priyanka SNK, Jha KK (2010) Benzothiazole: the molecule of diverse biological activities. Inter J Curr Pharm Res 2(2):01-06

14. Mehta A, Bhatt R, Sharma S, Patidar AK, Rathore KK, Senwar RC (2015) Synthesis, characterization and antimicrobial evaluation of some tetrahydroquinazoline derivatives of benzo[b]thiophene. Int J Pharm Sci Drug Res 7(5):417-420

15. Mazimba O (2015) Antimicrobial activities of heterocycles derived from thienylchalcones. J King Saud Univ Sci 27:42-48

16. Prasad KC, Angothu BN, Latha TM, Nagulu M (2017) Synthesis of some novel 2-aminothiophene derivatives and evaluation for their antimicrobial activity. Int J Pharm Bio Sci 7(1):01-07

17. Lakshmi N, Haritha V, Sreeram V, Rajalakshmi D, Sindhura N, Visagaperumal D (2009) Synthesis and their possible biological activities of few formazans of 3-amino-2-sulphanyl-2,3,4,5,6,7,8-hexahydro(1) benzothieno(2,3-d)pyrimidin-4(1H)-one. Rayasan J Chem 2(1):71-74

18. Havaldar FH, Bhise S, Burudkar S (2004) A facile synthesis of 10-methoxy4,8-dinitro-6H-benzothieno[2,3-c]chromen-6-one. J Serb Chem Soc 69(7):527-532

19. Ahmed MM, Matough FS, Farhat MF (2008) Synthesis and biological evaluation of some new thienopyridine and thienopyrimidine derivatives. Jord J Chem 3(3):223-232

20. Bhuiyan MH, Rahman M, Hossain K, Rahim A (2006) Synthesis and antimicrobial evaluation of some new thienopyrimidine derivatives. Acta Pharm 56:441-450

21. Khazi IA, Kumar N, Shetty S, Lamani RS (2009) Synthesis and antimicrobial activity of some novel thienopyrimidines and triazolothienopyrimidines. J Chem Sci 121(3):301-307

22. Tombary AA, Soliman R, Habib NS (2009) Synthesis of tetrahydrobenzothieno[2,3- $d$ ]pyrimidine and tetrahydrobenzothieno[3,2e]-[1,2,4]triazolo[4,3-c]pyrimidine derivatives as potential antimicrobial agents. Sci Pharm 77:755-773

23. Adiwish WM, Yaacob WA, Adan D, Nazlina I (2012) Synthesis and antibacterial activity of thiophenes. Int J Adv Sci Eng Inf Tech 2(4):27-30

24. Reheim AM, Baker SM (2017) Synthesis, characterization and in vitro antimicrobial activity of novel fused pyrazolo[3,4-c]pyridazine, pyrazolo[3,4-d] pyrimidine, thieno[3,2-c]pyrazole and pyrazolo[ $\left[3^{\prime}, 4^{\prime}: 4,5\right]$ thieno[2,3-d] pyrimidine derivatives. Chem Cent J 11:112-124

25. Bindu PJ, Mahadevan KM, Naik TR (2012) An efficient one-pot synthesis and photoinduced DNA cleavage studies of 2-chloro-3-(5-aryl-4,5-dihydroisoxazol-3-yl)quinolines. Bioorg Med Chem Lett 22(19):6095-6098. https://doi.org/10.1016/j.bmcl.2012.08.034

26. Dosari MS, Ghorab MM, Alsaid MS, Nissan YM, Ahmed AM (2013) Synthesis and anticancer activity of some novel trifluoromethylquinolines carrying a biologically active benzenesulfonamide moiety. Eur J Med Chem 69:373-383

27. Sankaran M, Kumarasamy C, Chokkalingam U, Mohan PS (2010) Synthesis, antioxidant and toxicological study of novel pyrimidoquinoline derivatives from 4-hydroxy-3-acylquinolin-2-one. Bioorg Med Chem Lett 20:7147-7151

28. Ghorab MM, Bashandy MS, Alsaid MS (2014) Novel thiophene derivatives with sulfonamide, isoxazole, benzothiazole, quinoline and anthracene moieties as potential anticancer agents. Acta Pharm 64:419-431 
29. Gunda SR, Lingala S, Allenki V (2017) Synthesis and anticancer activity of some novel 3-[(2-substituted-6,7,8,9-tetrahydro-5Hcyclohepta[b] thieno[2,3-d] pyrimidin-4-yl)amino]propan-1-ol derivatives. Eur J Pharm Med Res 4(6):481-484

30. Mohareb RM, Abdallah AE, Helal MH, Shaloof SM (2016) Synthesis and structure elucidation of some novel thiophene and benzothiophene derivatives as cytotoxic agents. Acta Pharm 66:53-68

31. Sharkawy KA, Sehrawi HM, Ibrahim RA (2012) The reaction of 2-amino4,5,6,7-tetrahydrobenzo[b]thiophenes with benzoyl-isothiocyanate: synthesis of annulated thiophene derivatives and their antitumor evaluations. Inter J Org Chem 2:126-134

32. Seley KL, Januszczyk P, Hagos A, Zhang L (2000) Synthesis and antitumor activity of thieno-separated tricyclic purines. J Med Chem 43:4877-4883

33. Mohareb RM, Shams HZ, Helal MH, Mahmoud AE (2011) Novel synthesis and antitumor evaluation of polyfunctionally substituted heterocyclic compounds derived from 2-cyano- $\mathrm{N}$-(3-cyano-4,5,6,7-tetrahydrobenzo[b] thiophen-2-yl)-acetamide. Molecules 16:52-73

34. Madhavi K, Soumya KR, Subhashini C (2017) Cyanoacetylation of substituted 2-aminothiophenes and evaluation for antioxidant and antibacterial activities. Res J Pharm Biol Chem Sci 8(2):387-394
35. Bahashwan SA, Fayed AA, Amr AG, Flefel EM, Kalmouch A (2013) Synthesis and pharmacological activities of some new triazoloand tetrazolopyrimidine derivatives. Molecules 18:15051-15063

36. Ouf NH, Amr AG (2008) Synthesis and anti-inflammatory activity of some pyrimidines and thienopyrimidines using 1-(2-Benzo[d][1,3]dioxol-5-yl) vinyl)-4-mercapto-6-methylpyrimidine-5-yl)ethan-2-one as a starting material. Monatsh Chem 139:579-585

37. Hafez HN, Duaij OK, Gazzar AB (2013) Design, synthesis and pharmacological evaluation of new nonsteroidal anti-inflammatory derived from 3-aminobenzothieno[2,3-d]pyrimidines. Inter J Org Chem 3:110-118

38. Rasool N, Noreen M (2015) Synthesis, density functional theory (DFT), urease inhibition and antimicrobial activities of 5-aryl thiophenes bearing sulphonylacetamide moieties. Molecules 20:19914-19928

39. Dashyan Paronikyan EG, Noravyan AS (2015) Synthesis and neurotropic activity of 2,4-disubstituted pyrano[ $\left[4^{\prime}, 3^{\prime}: 4,5\right]$ pyrido[2,3-b]thieno[3,2- $\left.d\right]$ pyrimidines. Russian J Bioorg Chem 41 (6):663-669

40. Zubair M, Rizwan K (2014) Regioselective synthesis of 2-(bromomethyl)5-aryl-thiophene derivatives via palladium (0) catalyzed suzuki cross-coupling reactions: as antithrombotic and haemolytically active molecules. Chem Cent J 8(74):1-8
Ready to submit your research? Choose BMC and benefit from:

- fast, convenient online submission

- thorough peer review by experienced researchers in your field

- rapid publication on acceptance

- support for research data, including large and complex data types

- gold Open Access which fosters wider collaboration and increased citations

- maximum visibility for your research: over 100M website views per year

At BMC, research is always in progress.

Learn more biomedcentral.com/submissions 